\title{
$[2]$
}

\section{Women for Hire? Sex and Gender in Domestic Service}

How and why did the development of a colonial labor force in Northern Rhodesia exclude African women from domestic service? The trajectory of what took place, namely men's prior entry into wage labor as a result of the administration's attempt to create a rural-urban division of labor by sex, is well known. To explain why and how it occurred, I go beyond functionalist explanations, according to which the division of labor is held to benefit capital by enabling it to pay substandard wages to male workers whose reproduction costs were borne by the unpaid work of women either on rural farmsteads or in urban households. ${ }^{1}$ I wish to demonstrate the implication of cultural factors in this process.

To be sure, any explanation of the gender division of labor in domestic service needs to be placed in the broader context of the new economic and political processes that were set into motion by the penetration of first settler, then mining, capital. It was also shaped by demographic factors and settlement patterns among the scattered white and African populations. Last, but not least, there were cultural and ideological factors, which on both the white and the African side of the colonial encounter affected the way each group constructed societal norms, the place of the two sexes in the system of social relations, and their images of each other.

In this chapter I attempt to unravel the various and changing roles that economic, demographic, political, cultural, and ideological factors played in

1. Lionel Cliffe, "Labour Migration and Peasant Differentiation: Zambian Experiences," Journal of Peasant Studies 5 (1978): 326-346, and George Chauncey, Jr., "The Locus of Reproduction: Women's Labour in the Zambian Copperbelt, 1927-1953," Journal of Southern African Studies 7 (1981): 135-164. 
structuring domestic service by gender. Cultural and ideological notions about sex and gender reinforced the convention, developed during the opening decades of colonial rule, of not employing African women as servants. As the economy changed, this convention was rationalized as commonsensical knowledge that white women did not want African women in their homes because their sexuality was threatening. Because this argument, in the words of an observer of race relations in the 1950s, "reveals an assortment of lust and fears that were usually kept out of sight and about which it [was] not polite to talk, "2 I have marshaled evidence and made deductions from sources other than conventional historical documents. My concerns are with a battery of gender images shaped in the early days of contact between a primarily male white population and local African women and men. I trace how they were produced-as opposed to whether they are true or false-through an examination of contemporary texts concerning the nature and effects of interactions between and among whites and Africans of both sexes from the turn of the last century onward. Many disparate elements comprise the discourse, and their relative weight in the overall characterization changed over time, accommodating to a small degree the shifts in colonial society and the world beyond it. Yet the outcome remained fixed, for Africans remained different, other, ${ }^{3}$ and African women in Northern Rhodesia even more so, inferior to their men and most certainly to white women.

\section{The Rural/Urban Division}

Before the Great Depression, the potential supply of African women for urban wage labor was limited. The system that supplied migrant workers to farmers, businesses, small mines, and private householders within and outside Northern Rhodesia was geared exclusively toward men. They worked on temporary contracts, housed and fed by employers for the duration, after which they were expected to return to their villages. The administration was concerned to prevent the growth of an urban African proletariat and considered the village and the tribe to be the permanent reference point for migrants.

The viability of village life depended overwhelmingly on the work of women, for in his region's agricultural system they played the major pro-

2. Quoted in Patrick Keatley, The Politics of Partnership: The Federation of Rhodesia and Nyasaland (Harmondsworth: Penguin, 1963), p. 269.

3. Mary Louise Pratt, "Scratches on the Face of the Country; or What Mr. Barrow Saw in the Land of the Bushmen," Critical Inquiry 12 (1985), pp. 119-122. 


\section{A Fixture of Colonial Society}

ductive role. Men could more easily be dissociated from their villages, especially if they returned at critical points during the cultivation season when their labor was most needed. ${ }^{4}$ In the colonial scheme, it was very important to keep women back on the farm. Their work subsidized migrant workers' substandard wages and ensured the reproduction of a new generation of workers without cost to the administration. Despite the reserves policy, which reduced the available land for many African groups, and marketing decisions that adversely affected the price of their produce, African' farm output did not disappear from the market. As long as it remained profitable to participate in the food market, many African women continued to depend on their fields for income, supplemented by remittances from absentee husbands, brothers, and sons. Before the 1930s special policies would have been necessary to extract that rural female labor supply for work in the cities had the economy needed their labor power. Thus the question of using African women for urban domestic service did not arise: they were hardly available.

These circumstances changed once the slump had ended and many more men went on labor migration. In some societies, such as the Bemba, where hunger had been a recurring seasonal phenomenon, malnutrition became more prevalent. ${ }^{5}$ Women, children, and old people on the reserves were unable to meet their own demands for food without permanent support from men. Various studies from the 1930s onward indicate a growing gap in food consumption between African rural and urban populations. ${ }^{6}$ More women and children migrated to the towns, sometimes alone, at other times accompanied by husbands, fathers, or guardians. During World War II, when Northern Rhodesia experienced extreme food scarcities, the colonial government tried to stem this urban influx, devising a variety of measures to get women and children back to where they belonged: the villages, as food producers. These attempts were largely ineffectual. This observation suffices here to demonstrate that by the time of the post-World War II campaign for African womanpower, there was a large supply of urban African women from whom white householders could have recruited servants.

4. Audrey I. Richards, "Bemba Marriage and Present Economic Conditions," RhodesLivingstone Papers, no. 4 (1940); William Watson, Tribal Cohesion in a Money Economy (Manchester: Manchester University Press, 1958); and Jaap van Velsen, The Politics of Kinship (Manchester: Manchester University Press, 1964).

5. Richards, "Bemba Marriage."

6. Betty Preston Thomsen, "Two Studies in African Nutrition," Rhodes-Livingstone Papers, no. 24 (1954); Bruce Fetter, "Relocating Central Africa's Biological Reproduction, 19231963," International Journal of African Historical Studies 19 (1986): 463-478. 


\section{The Sexuality Argument}

In Northern Rhodesia the demand of white colonists for servants was shaped by factors that construed a good servant as a man. White attitudes to African women revolved around sexual anxiety. This anxiety meant different things to different people, depending on their sex, race, and class. It first and foremost meant white men's sexual need for African women, and white women's uneasiness, concern, and fear caused by the knowledge of such sexual encounters. This sexual anxiety runs as a single common thread through the entire colonial period, providing an important key to understanding the gender division of labor in white servant-keeping households.

\section{The Cook's Woman}

The question of sexual relations with African women was "of obvious interest," states Alan Cairns in his study of British reactions to Central African society before the imposition of BSAC administration in the $1890 \mathrm{~s} .{ }^{7}$ This interest did not abate with the coming of British colonial rule but persisted in conflict with or accommodation to the cultural norms and social pressures that gradually emerged within the slowly growing white population among whom the sex ratio remained skewed till about World War II.

The "simple life" of the earlier period, as described by a pioneer from North Eastern Rhodesia, included the change from the "palmy days of transition, when there were no game laws, reserves, or licenses necessary, and when men could and did shoot scores of elephants, "8 to the stepwise introduction of a civil administration, taxation, the building of roads and bridges, the establishment of a postal system, and the building of railways. Slave-trading Arabs had been eliminated, gunrunning reduced in scale, and white missionaries, hunters and prospectors, traders, farmers, and administrators began to settle down more peacefully to the task of adopting the "exigencies of an African environment to their own standards of comfort and well-being."9 Regardless of occupational background they all needed

7. H. Alan C. Cairns, Prelude to Imperialism: British Reactions to Central African Society, 1840-1890 (London: Routledge and Kegan Paul, 1965), p. 53. For a general discussion, see Ronald Hyam, "Empire and Sexual Opportunity," Journal of Imperial and Commonwealth History 14 (1986): 34-90.

8. Dugald Campbell, In the Heart of Bantuland: A Record of Twenty-nine Years' Pioneering in Central Africa among the Bantu Peoples, with a Description of Their Habits, Customs, Secret Societies, and Languages (1922; New York: Negro Universities Press, 1969), pp. $298,304$.

9. Robert I. Rotberg, Christian Missionaries and the Creation of Northern Rhodesia, 1880-1924 (Princeton: Princeton University Press, 1965), p. 49. 


\section{A Fixture of Colonial Society}

menservants to minister to their household needs. Their cooks often procured "the cook's woman," as she came to be known, who provided sexual services to the master on a temporary or longer-term basis.

Among some whites there was a partial equation of frontier life, up to and including the early years of the BSAC administration, with sexual freedom and indulgence. Their response to sex across the racial divide depended to some extent on their occupation and relative standing in the evolving hierarchy of white colonial society. The ethical and moral norms of missionaries prohibited them from sexual intercourse with African women, but traders and hunters felt no such obligations. ${ }^{10}$ Although exact figures are difficult to obtain, "what information there is available indicates that the practice was widespread, despite many attempts to stamp it out."11

Little is preserved in the written record of what later contemporaries said and thought about the sexuality issue. Outside of all-male mess parties, it might not have been discussed. What remains is scattered between the lines of travel descriptions, memoirs, and colonial dispatches, and can be gleaned from the retrospective, almost all male writings in publications from the 1950s and on, when the days of grand patriarchs and women who knew their place were reckoned soon to be a bygone era. The images such texts convey are twice refracted, as it were. They celebrate the good old days, which were hardly romantic but tough, and they speak in a libidinous voice about sexual relations, which in the tense racial atmosphere of the 1950s were considered an impolite topic for public discourse. While some of the evidence is necessarily anecdotal, it nevertheless portrays practices that were the rule rather than the exception during the first decades of white settlement.

The tropical habit of keeping a cook's woman developed during the pioneer era under frontier conditions where a small, nearly all male population required physical cooperation across race at a time when a class barrier had not yet been established (See Tables 2 and 3). R. MurrayHughes recalls life at Kafue-Namwala about 1912: "Among all those stalwart, healthy, young - and old — pioneers, whatever their calling - administrators, police, traders, farmers or miners-there were no psychopathic cases ... . : our community was essentially sane; and this was due to an institution known as 'the cook's woman,' which she was not. An arrangement openly acknowledged in the neighbouring Belgian and Portuguese territories had to be camouflaged in an English colony where Mother Grundy still ruled; and much less being allowed the run of the house and

10. Cairns, Prelude, pp. 54-55.

11. Lewis H. Gann, A History of Northern Rhodesia; Early Days to 1953 (New York: Humanities Press, 1964), p. 151. 
Table 2. European population of Zambia, by year, 1904-1965

\begin{tabular}{cc}
\hline Year & Population \\
\hline 1904 & 850 \\
1907 & 1,050 \\
1911 & 1,407 \\
1921 & 3,634 \\
1925 & 4,620 \\
1927 & 7,540 \\
1930 & 14,000 \\
1931 & 13,846 \\
1932 & 10,550 \\
1934 & 11,460 \\
1935 & 12,000 \\
1940 & 15,190 \\
1946 & 21,907 \\
1951 & 37,079 \\
1954 & 53,000 \\
1956 & 65,277 \\
1957 & 72,000 \\
1958 & 71,000 \\
1960 & 73,000 \\
1961 & 74,640 \\
1962 & 77,000 \\
1963 & 76,000 \\
1964 & 74,000 \\
1965 & 70,000 \\
\hline
\end{tabular}

Source: George Kay, A Social Geography of Zambia (London: London University Press, 1967), p. 26.

given a status equivalent to the Chinese concubine, our 'mistress' was given her clothes and monthly allowance in the usual English manner." 12 Most of the hunters, transport riders, and traders of this era adopted an "African way of life" and had either one of more African wives, writes Richard Sampson in his biography of George Westbeech, trader and hunter, one of the first whites to enter into and settle in this region. The strain between him and his South African-born white wife grew because of his drinking and sexual habits and culminated in her return to the Transvaal in 1877. She had heard too many stories of his consorting with African women up and down the Zambezi Valley. With her Boer condemnation of mis-

12. R. Murray Hughes, "Kafue-Namwala in 1912, Part 2," Northern Rhodesia Journal 5 (1962): 106. 


\section{A Fixture of Colonial Society}

Table 3. Age and sex structure of the European population of Zambia, 1911-1956

\begin{tabular}{ccccc}
\hline Year & $\begin{array}{c}\text { Males as \% } \\
\text { of total } \\
\text { population }\end{array}$ & $\begin{array}{c}\text { Women } \\
\text { (over 20 years) } \\
\text { per 100 men }\end{array}$ & $\begin{array}{c}\text { Men aged 25-44 } \\
\text { years as \% of } \\
\text { total population }\end{array}$ & $\begin{array}{c}\text { Children under } \\
\text { 15 years as \% of } \\
\text { total population }\end{array}$ \\
\hline 1911 & 74.5 & 17.5 & 49.0 & 15.5 \\
1921 & 62.5 & 48.0 & 30.0 & 25.0 \\
1931 & 63.0 & 48.5 & 29.0 & 21.0 \\
1946 & 51.5 & 91.0 & 20.0 & 29.0 \\
1956 & 53.0 & 83.0 & 22.0 & 33.0 \\
\hline
\end{tabular}

Source: George Kay, A Social Geography of Zambia (London: London University Press, 1967), p. 27.

cegenation, she was still saying forty years later how ashamed she was to have been married to Westbeech because of his sexual activities. ${ }^{13}$

Although BSAC administration was imposed over these northern territories in the 1890s, it was fragmented and scattered, leaving room for enterprise in business and administration as well as in matters of sex. Some white men set themselves up as, or were made, chiefs and settled down almost as feudal lords, according to W. V. Brelsford's recollections of pioneer days. Such was the case of Harrison Clark, known as "Changa Changa," who made a treaty with a chief in the Portuguese East Africa border region. Because he was not placed in a BSAC post, he complained to the company office in Salisbury, arguing that he carried out the tasks of most of the company's administrators: he collected hut tax in kind (grain, chickens, and cattle) and seized one tusk of every elephant killed in the country. Whenever he saw "a girl he [fancied] he [took] her as his mistress for a few days, and when tired of her, he [sent] her home"; he had even taken one of the chief $\mathrm{s}$ wives. ${ }^{14} \mathrm{In}$ the same region near Feira lived another trader, "Kachachola" Bloomfield, who is said to have had at least eight or nine African wives and to have left at least thirty-six children among them. ${ }^{15}$

Sexual relationships between white men and African women were most common in those areas with good potential for trade and hunting-for example, in the Caprivi Strip and in Barotseland-or for other employment, such as the construction of the Bulawayo-Katanga railroad. ${ }^{16}$ When

13. Richard Sampson, The Man with a Toothbrush in His Hat: The Story and Times of George Capp Westbeech in Central Africa (Lusaka: Multimedia Publications, 1972), pp. 13,69 .

14. W. V. Brelsford, Generations of Men: The European Pioneers of Northern Rhodesia (Lusaka: Government Printer, 1965), p. 24.

15. Ibid., pp. 70-71.

16. For more discussion, see Cairns, Prelude, pp. 55-57, and ibid., pp. 96-109. 
railway building halted for about two years at Broken Hill in 1906, most of the white workers settled down with African women. ${ }^{17}$ Labor recruiters met at Sesheke on the Zambezi River to recruit a quota of workers from Barotseland and to return them on completion of their contracts in the south. There was also a market for the sale of cattle from Barotseland and from North Eastern Rhodesia. It was here at Sesheke that traders congregated, doing most of their business once the African workers came upriver returning from migrant work. For most of the time these white men hunted, fished, and had "affairs with the Lozi women." 18 One of this band of traders who lived and died on the Zambezi in Barotseland was Arthur Harrington, about whose household many stories were told. He was said to have six African wives, whom he would visit, each in her own hut, according to a carefully checked schedule. ${ }^{19}$

The most famous of these men set up their menages in quasi-feudal style. Among them were Arthur Davidson, one of the biggest landowners in Northern Rhodesia, who was so fond of African women that he entertained two at the same time in his castle in Ndola. ${ }^{20}$ Best known of all was "Chirupula," alias J. E. Stephenson, who helped open up the Kafue Hook and what became the copperbelt to the BSAC administration. In soap opera fashion, his biographer relates how he "went native," first with a woman procured by the cook, and next with an African princess. ${ }^{21}$ In his own biography, Stephenson said very little about his African wives or about the nature of their household. He does note that "in those parts and in those days there were no European women. . . But there were lots of women-ladies, too, if you like-of a different complexion: there was no scarcity at all." $22 \mathrm{He}$ resigned in 1906, allegedly after he was refused promotion because of flaunting civilized norms. He then took up farming in the Mkushi district and built a strange-looking castle, which he called Stonehenge. Stephenson's biographer notes that most of his acquaintances "kept native concubines . . . only as long as European society remained strictly masculine, but as soon as white women appeared in the outposts, they sent the African girls back to their villages, and their golden-skinned babies were either farmed out to some sympathetic missionary or left to wander in the wilderness." 23 Stephenson himself had not done so; he

17. Dick Hobson, "Recollections of Captain John Brown," Northern Rhodesia Journal 3 (1958), p. 516.

18. Brelsford, Generations, p. 96.

19. Ibid., p. 114.

20. Ibid., p. 142 .

21. Kathaleen Stevens Rukavina, Jungle Pathfinder: Central Africa's Most Fabulous Adventurer (New York: Exposition Press, 1950), pp. 57-67.

22. J. E. Stephenson, Chirupula's Tale: A Bye-Way in African History (London: Geoffrey Bles, 1937), p. 29.

23. Rukavina, Jungle Pathfinder, pp. 143-147. 


\section{A Fixture of Colonial Society}

publicly recognized his children and supported them. And he complained of the coming of the "ubiquitous Nosey Parkers" who declared that men "who lived naturally-legally . . . according to the ways of the country and the period-were 'living in sin'." 24

The private menages of Davidson and Stephenson were the frills on an increasingly race-conscious colonial society, tolerated because of these men's pioneering roles but certainly no longer comme il faut. In a voice that puts women in their place, Brelsford comments that "some white ladies probably felt quite daring and advanced by receiving such renegades as Davidson and Stephenson in their homes. "25 If he had let them speak for themselves, he may have learned that such ladies might not have wanted to do so, judging from comments about men who had "gone native" made by Barbara Carr from fort Jameson in the 1940s: "I noticed with disgust in the club at Christmas . . . that one or two of the older bachelor game rangers ... whom I knew lived with native women, were dancing clumsily with the sweet, innocent teenage daughters of some of the townspeople and my blood boiled. These men had an uncomfortable look in their eyes when we wives spoke to them and I now watched them with disgust." 26

White men's days of carefree sex belonged to the pioneer era. While prejudice increased in the small but slowly growing white settlements along the line-of-rail, these practices persisted where there was less social pressure to conform, especially in bush stations. In her account of life at Fort Jameson in the 1920s, Winifred Tapson noted the commonality of interracial sexual cohabitation and the "hiding everywhere . . of little scatterings of half-caste children." In her view, the loneliness of pioneers absolved them: "those men are hardly to be blamed for rejecting in their self-chosen exile, a life of monastic exactitude." 27 By that time, however, colonial authorities took a hostile view on concubinage and cohabitation, deeming such relations as unfitting for men in positions of authority. The official stance, however, did not necessarily reflect actual practice. One case, discussed at length in the colonial correspondence just before 1910 , illustrates this ambivalence.

This case arose in the wake of complaints made by Charles Venables, a farmer near Chirundu, who alleged that Native Commissioner MacNamara of Guimbi (now Gwembe) subdistrict, had inflicted brutal assaults on Africans for not paying taxes. In the ensuing correspondence, Venables threw in the additional allegation that MacNamara cohabited with African wom-

24. Stephenson, Chirupula's Tale, p. 29.

25. Brelsford, Generations, p. 143.

26. Barbara Carr, Not for Me the Wilds (Cape Town: Howard Timmins, 1963), p. 175.

27. Winifred Tapson, Old Timer (Cape Town: Howard Timmins, 1957), p. 19. 
en. ${ }^{28}$ These charges were proven true and MacNamara dismissed in 1910 for "having habitually practiced concubinage with a native woman. This practice is most degrading to a white officer . . . and incompatible with the maintenance of the prestige of a British Government." 29 That same year, one Mr. Graham brought similar charges against R. L. Harrison, native commissioner of Mkushi, who after a severe reprimand was allowed to remain in his post, because he had recently married a European woman. ${ }^{30}$

Matters involving Venables did not end at that point. A letter from the high commissioner's office in South Africa noted that Venables had "been in the practice of cohabiting with native women." He was reprimanded and told he was not entitled to criticize since his own conduct was "calculated to degrade the white man in the eyes of the black and to impair the prestige of the governing race." 31 Provoked, Venables dispatched an accusatory fusillage to the imperial secretary in London, excusing himself by his youth and loneliness and by reference to the commonality of concubinage. His charges included officials within the Northern Rhodesian administration and read in part:

I beg to remind you that His Majesty's Government have within recent years permitted the territories of North Eastern and North Western Rhodesia to be administered by an official who kept a plurality of native concubines ... [and] are now permitting and have permitted for years the district administration of these territories to be conducted by a staff of officials a large proportion of whom keep or have kept native concubines . . [or even] made a practice of cohabiting indiscriminately with native women throughout their districts. . . . There are scattered throughout these territories half-caste children and families of half-caste children, the offspring of . . . officials. . . . One of these territories in fact, has been administered by an official who kept a veritable harem of native women. ${ }^{32}$

Venables's accusations caused an uproar, prompting confidential and official dispatches among these northern territories, Cape Town, and London.

28. The brutality charges, but not the sexuality issue, are discussed in Fergus Macpherson, Anatomy of Conquest: The British Occupation of Zambia, 1884-1924 (London: Longman, 1981), pp. 123-128.

29. PRO/CO 417/482. Telegram from High Commissioner, Johannesburg, to Acting Administrator of North Western Rhodesia, Livingstone, about MacNamara. April 11, 1910.

30. PRO/CO 417/485. Letter from Imperial Secretary C. H. Rodwell to Harrison. September 13, 1910. Gann and Duignan refer to a 1909 case of an early official, R. A. Osborne, who had flogged and fined and then sacked his African cook, whom he found sleeping with his "African wife." L. H. Gann and Peter Duignan, The Rulers of British Africa, 1870-1914 (Stanford: Stanford University Press, 1978), pp. 241, 387 n. 56.

31. PRO/CO 417/482. Letter from Imperial Secretary C. H. Rodwell to C. N. B. Venables. April 21, 1910.

32. PRO/CO 417/493. Letter from Venables to the Imperial Secretary. May 11, 1910. 


\section{A Fixture of Colonial Society}

High Commissioner Lord Gladstone read Venables's letter as a straightforward explanation and accepted his statement that although he had had relations with an African woman of superior background, that is, royal descent, he had not practiced concubinage with native women. But he took exception to the implication of the last part of Venables's letter, that the high commissioner was condoning concubinage. ${ }^{33}$

The acting administrator of North Western Rhodesia in Livingstone, L. A. Wallace, could not let Venables's remarks pass unchallenged either. For when Venables charged that North Eastern and North Western Rhodesia had been administered by officials who kept a harem of native concubines, the persons referred to could only be Codrington, the former resident administrator, and Wallace himself. Codrington died in 1902 and Wallace had never seen or heard any sign of his "plurality of concubines." If the statement referred to himself, "it could so easily be proved to be an absolute lie without the most far fetched, most flimsy foundation on fact." Wallace was perturbed because of the publication of a recent novel that featured Codrington under a scarcely disguised name as administrator of North Western Rhodesia and told the same story of an administrator of North Eastern Rhodesia "with the same morbid presumption of official vice." 34

These dispatches highlight the sensitivity of the sexuality issue. While in the official view concubinage had been condoned in the pioneer days and perhaps accepted as a liability of hunting and trading life, it could not continue. Metropolitan prudery had to be reckoned with. To that effect a confidential letter was circulated throughout the BSAC territories. ${ }^{35}$ The amount of disagreement it engendered reveals that the practice was more widespread than the administration figured.

Local dissent, and the ambivalence surrounding the sexuality issue, is brought out squarely in a letter sent by the acting administrator of North Eastern Rhodesia at Fort Jameson to the high commissioner in South Africa in response to the circular on concubinage. In L. P. Beaufort's opinion:

33. Ibid. Letter from the Imperial Secretary to Venables. June 6, 1910.

34. Ibid. Letter from L. A. Wallace to Lord Gladstone, September 30, 1910.

35. The confidential letter on concubinage mentioned in the colonial correspondence has not been retained in the official files. It is not the confidential circular on concubinage issued by the Colonial Office in London in 1909 and distributed in two different versions to a selection of colonial dependencies. That 1909 circular was not distributed in the areas over which the high commissioner in South Africa was in charge, i.e., Basutoland, Bechuanaland, Southern Rhodesia, and North Western Rhodesia, nor was it sent to North Eastern Rhodesia, then under the Crown Colonies Department. PRO/CO 854/196. Colonies General. Circular Despatches. Confidential and Secret Circulars, 1907-1915. Longhand list of distribution of circulars. January 11, 1909. See also Ronald Hyam, "Concubinage and the Colonial Service: The Crewe Circular (1909)," Journal of Imperial and Commonwealth History 14 (1986): 170186. 
Concubinage of a European with a single native woman, maintained with constancy and decently veiled, stands on a footing so different (from promiscuity, libertinage, and general incontinence) that it would be of very doubtful justice or expediency to condemn it before it had given rise to scandal or trouble. . . . Were I to be told that any proved case of concubinage, apart from its ill consequences, should be severely dealt with, I should doubt the wisdom of the order.

Such a concubinage is often defended on many grounds, e.g., a. health, b. the acquirement of native language, $c$. ideas and mode of thought, $d$. and the warning of projected crimes and risings. It has been e. of material comfort and advantage to many a lonely European, $f$. it is not the least degrading to the women of this country, nor the least likely in itself to give rise to native trouble, $g$. if it does not enhance the official's status in the native eye, it at least saves him from the contempt of many among them and from the suspicion of the worst moral state they are apt to impute to a man living by himself.

Concluding, Beaufort remarked: "if [the circular] is intended to threaten displeasure at every case of concubinage, I would respectfully dissent from its expedience or justice. ${ }^{36}$ To this, the high commissioner duly but tersely replied that it was both undesirable and impossible that the practice of concubinage with native women, which "repeatedly had been the cause of great scandal in the past," should receive either countenance or condonation. ${ }^{37}$

Concubinage, as described in these dispatches, implied enjoyment first and sin as an afterthought. White men wanted to have their cake and eat it too, decently veiled, and the colonial administration, at least at this point in time, was unable to regulate local sexual mores. Of MacNamara, a later source reports that he was reinstated after a temporary suspension and became employed at Livingstone as a labor agent. ${ }^{38}$ And the story continued of Venables, who had helped stir the uproar. Enjoying a very comfortable remittance from Britain, on his farm about 1912, "he didn't live alone by any means. His companions were half a dozen little maids, who, he insisted were all daughters of chieftains and princesses in their own right." 39

Concubinage persisted in Northern Rhodesia, not only in outlying districts but in the towns along the line-of-rail, among prospectors, traders of

36. PRO/CO 417/484. Confidential Letter from Acting Administrator of North Eastern Rhodesia L. P. Beaufort to the South African High Commissioner. October 4, 1910. In all the records consulted for this region, this is the only one containing a reference to homosexuality, albeit obliquely.

37. PRO/CO 417/484. Letter from Lord Gladstone to Beaufort. November 14, 1910.

38. Tom Chicken, "Memoirs of Abandoned Bomas No. 3: Ibwe Munyama, Part 2, Northem Rhodesia Journal 3 (1958), 419. But see MacPherson, Anatomy, p. 125, who disputes this.

39. Hughes, "Kafue-Namwala," p. 106. 
various nationalities, and officials, and everyone knew of it. As white society became increasingly race conscious, British people in positions of influence, like Beaufort, made a great fuss, emphasizing the need at least to cloak the practice. "Not even the lowest [white man] on the social and moral scale would ever dream of offending the susceptibilities of white women by parading his black paramour in a place where white women lived," commented a newspaper contributor after a visit to Elizabethville in the Congo in 1912. "Not so the Belgians in Katanga." This incensed writer described how he had seen a fully uniformed Belgian officer walk down Elizabethville's main avenue arm in arm with his native woman and in passing greet a white woman accompanied by her husband. He had on another occasion refused to be seated at a Belgian officer's table laid out for three until the "unofficial black wife" had been relegated to the kitchen. ${ }^{40}$ In Northern Rhodesia, although the practice normally was never discussed openly, concubinage was considered acceptable so long as white men did not display their black mistresses in public. That opinion persisted among some segments of white society up to the eve of independence when one of them, who disapproved of the way developments were turning, said to a friend: "I don't 'old with it. I don't 'old with it-. They will be dancing with 'em next." 41

"Miscegenation certainly occurred," states Gann, though "its full extent is difficult to gauge. . . . Documentary and verbal evidence . . . makes it seem likely that intermingling occurred more often than the census figures indicate; it is likely that the enumerations failed to keep count of a number of coloured children living with their mothers in the villages. ${ }^{42}$ These children lived "in the manner of the Africans," as members of the legislative council termed it in later years when they with embarrassment recognized the "unfortunate practices leading to the production of half-castes ... in earlier days." Such children were distinguished from those who lived "after the manner of Europeans . . . many of whose fathers were men of good standing and education, university men, civil servants, expert engineers, etc." 43 Those special few, that is, the African women kept on a long-term basis by men such as Davidson and Stephenson, became the founding ancestresses of descent groups that are readily recognizable in Zambia today.

But such men were exceptions. Most white men took African women in the way they had taken everything else, land and labor, and when it was not forthcoming, then by force. Regardless of the purported motive of

40. "Conditions in Katanga," Livingstone Mail, December 14, 1912, p. 7.

41. Gervas Clay, personal communication, January 15, 1986.

42. Gann, History, p. 184.

43. Northern Rhodesia. Legislative Council Debates 33 (1939); May 20-June 6, cols. 196197. 
replacing slavery with civilized trade, huntes, traders and prospectors, missionaries, and administrators were all in search of game-trophies and ivory, mineral wealth, customers, souls, land, or subjects to administer. The use of extraeconomic means in this process has been well documented but its sexual dimension has barely been explored. ${ }^{44}$ As African men were coerced into wage labor through the tax nexus, so many African women were taken from their local groups at white men's behest and against their own wishes. Chirupula's infatuation with his "ebony Venus" seems an exception and is perhaps overdramatized by his romanticizing biographer. ${ }^{45}$

Glimpses of how white men got their "game" exist among the evidence in the MacNamara and Harrison cases in 1910. Men servants would be dispatched to a village to find a woman. Sometimes a chief or headman would be asked if he had a young woman to spare; at other times servants would procure women, using their powers of persuasion or coercion. Presents, such as a shawl or money, might pass hands as well. To please their masters, servants would at times bring them women without having been asked. These women would then stay at the white man's place for the night, or a few days. While on tour as well, white men would seek out women for sex. Once MacNamara "had come all through the district and had not been able to get a girl; at each village [he] only saw the old hags who brought out the grain." 46 When taking a woman, the white man or his African servant might inquire about her marital status. Unmarried girls seem to have been preferred, perhaps to avoid troubles with husbands, fathers, or guardians. Yet a Lala woman implicated in the Graham v. Harrison case was divorced by her husband on her return from Harrison's. ${ }^{47}$ Thus not all African men may have approved the practice.

The relationship of the pioneering generation of white men to Africa and her peoples was thus largely one of an expropriation. Such relations helped create, among others, the twin characters of the male domestic servant and the cook's woman, who, however, became differentially incorporated into the racially divided and class-structured society that was taking shape around them: African men providing labor power and African women providing sexual services. In this new division of labor, African men performed a role that had no parallel in the societies from which they came, whereas women's role was constructed in terms of their sex and by functions assumed to be primordial. Whites saw African women, as I discuss shortly, as

44. On coercion, see Macpherson, Anatomy, pp. 57-201; on imperial history and sex, see Hyam, "Empire and Sexual Opportunity."

45. Rukavina, Jungle Pathfinder, p. 62.

46. PRO/CO 417/482. Guimbi Subdistrict Inquiry, North Western Rhodesia. Extracts from the evidence, Venables v. MacNamara, pp. 343-344. April 25, 1910.

47. PRO/CO 417/483. Mkushi District Inquiry, North Western Rhodesia. Extracts from the evidence, Graham v. Harrison, p. 127. January 1910. 
available Madgalens. The administrators' discussion about concubines and cohabitation is therefore more than a tempest in a teacup: it reaches to the core of the nature and definition of the relation of white to black and is of course centrally concerned with the construction of sexuality.

\section{Black and White Perils}

White reactions to sex between men of the dominant race and women of a conquered race have varied widely. In his comparative historical analysis, George Fredrickson has shown that white South Africans condoned such relations much longer than the white colonists in North America. Such reactions do change, however, and by the period covered in this chapterthat is, from the beginning of this century up to World War II-white South Africa had closed in upon itself and had made such relations illegal under the law. Fredrickson attributes this development to differences in the social and political conditions in the two societies. In his view, such conditions serve better to explain white reactions to race mixing than do cultural ideas of, for example, attractivenes or compatibility, ${ }^{48}$ or at least they are more readily supportable from the historical record.

Sexual relations between white men and African women and a convention of employing men servants persisted longer in Northern Rhodesia than in the countries to the south. This persistence was due in part to demography and economic and political developments that helped texture the sexual aspect of the system of race relations in different ways in the north and the south.

In the early 1900s, the white-to-black population ratio and the proportion of white women to white men were much higher in the south than in Northern Rhodesia. The white South African population had by then established a sense of civilized life in which white women's presence was a powerful incentive to end concubinage. White Southern Rhodesians, although they lagged behind their South African neighbors in these respects, were already intent on creating a white man's country in the territory and on getting rid of BASC rule, and they were far ahead of Northern Rhodesia in terms of population and sex ratios. ${ }^{49}$ The economies of South Africa and

48. George M. Fredrickson, White Supremacy: A Comparative Study in American and South African History (New York: Oxford University Press, 1981), p. 125.

49. In South Africa in 1904 there were 111,700 whites and 349,100 Africans, and in 1911 the whites formed 21.4 percent of the total population, according to Pierre L. van den Berghe, South Africa: A Study in Conflict (Berkeley: University of California Press, 1970), p. 288 , table 2. There were 431 white women to 569 white men per 1,000 in 1904, a ratio that had evened out by 1926 to 490 women to 510 men, according to Southern Rhodesia. Report of the Director of Census, Regarding the Census Taken on the 4th May, 1926, Part I (Salisbury: Government Printer, 1927), p. 14. In 1904 in Southern Rhodesia there were 12,623 whites (South Africa: Census Returns of British South Africa [London: HMSO, 1904], p. 20), and 
Southern Rhodesia were more developed than in the north, where the white population was small and dispersed across the country in tiny settlements that grew slowly till the postdepression if not the post-World War II years (see Tables 2 and 3). In the context of this fairly unsettled and scattered white population whose self-consciousness and community were still in the process of being formed, white women householders' efforts to create and uphold a civilized way of life turned into anxiety. "Civilization" was threatened by crossracial sex between white men and African women. "European women," according to Gann, "were incensed at the idea of liaisons between white men and black women which they considered to be degrading to both, while men, especially those living on lonely farms, sometimes worried what might happen to their womenfolk if they were left alone amidst backward tribesmen." 50 This statement is only partially correct. White women disliked the thought or the knowledge of sexual involvements between white men and African women. But numerous observers, who lived in or passed through Northern Rhodesia, commented on the unproblematic relationship between white women and African men, and I return to this issue shortly.

The sexual anxiety in Northern Rhodesia centered on African women, not men. This fact helps explain why whites in the north did not share the "black peril" hysteria that swept South Africa and Southern Rhodesia before World War I, when white women on an unprecedented scale accused their African menservants of rape. In my view, this difference between north and south was shaped by the nature and extent of white men's sexual encounters with African women in the early decades of settlement in Northern Rhodesia, by the persistence and condoning of such practices during later years, and, as I discuss below, by the image whites constructed of African women's sexuality. "Nothing so embittered 'race relations' in urban South Africa before the First World War," comments Charles van Onselen in his dramatic study of the Rand, "as these 'black peril' scares, and nothing has been so little studied."51 Since the Southern Rhodesian scare has to my knowledge received scant scholarly attention, and since news of it filtered across the Zambezi, I have chosen to discuss it to highlight the contrasting sexual anxieties of the two territories.

289 white women to 711 white men per 1,000 . The unbalanced white sex ratios had evened out by 1926 to 443 women to 557 men per 1,000 (Southern Rhodesia: Report . . of Census, p. 14). In Northern Rhodesia (see Table 2) the white population numbered only 850 in 1904. 1 have found no white sex ratios for that year. Only by 1946 had the white sex ratio in Northern Rhodesia evened out to 91.0 women to 100 men (see Table 3), yet by 1956 it had dropped to 83.0 women to 100 men. The early censuses in Southern and Northern Rhodesia give no estimates for the white proportion of the total population.

50. Gann, History, p. 200,

51. Charles van Onselen, Studies in the Social and Economic History of the Witwatersrand, 1886-1914, vol. 2, New Nineveh (London: Longman, 1982), pp. 45-46. 


\section{A Fixture of Colonial Society}

Southern Rhodesian and South African whites were outraged when the high commissioner in South Africa, Lord Gladstone, in 1910 commuted the death sentence of houseboy Alukuleta, who was alleged to have attempted to rape a white woman in Umtali, a town on the border between Southern Rhodesia and Portuguese East Africa. Letters to the press called for stringent laws to protect white women. There were mass meetings in Bulawayo and on the Rand in March 1911.52 "The Women of Rhodesia," that is, Southern Rhodesia, sent a petition to the secretary of state for the colonies, calling for protection by the law, explaining, "Our homes lie in scattered townships and on isolated farms, and we are alone for the greater part of the day with male natives, who are practically the sole domestic servants obtainable. These natives are only savages, often thus brought in contact for the first time with civilization. . . . [White] men could not bring their wives here, nor rear their daughters in this country without making stringent laws to protect them. "53 There is evidence of scattered "black peril" cases in Southern Rhodesia during subsequent years. ${ }^{54}$ Yet "black peril" was not objectively a real epidemic of rapes by black men of white women in that country. It was rather a subjective construct of the white mind, a product of social interaction informed by a master-servant relationship, the logistics of which intimately threatened the hierarchical structure of the white colonial household. The class barrier, masked by race, had to be maintained, and in both South Africa and Southern Rhodesia laws against intermarriage and miscegenation between white men and African women were passed. ${ }^{55}$ The underlying sentiment is expressed in one of many

52. NAZIM/S 144/4,5. BSAC Administration. Black Peril, 1910-1912. See also Philip Mason, The Birth of a Dilemma: The Conquest and Settlement of Rhodesia (London: Oxford University Press, 1958), pp. 246-253, and Dane Kennedy, Islands of White: Settler Society and Culture in Kenya and Southern Rhodesia, 1890-1939 (Durham, N.C.: Duke University Press, 1987), pp. 138-147.

53. PRO/CO 417/496 no. 141. The Black Peril, Southern Rhodesia. Petition from the Women of Rhodesia, 1911.

54. Rape statistics were collected in Southern Rhodesia at least through 1918. About 30 cases were reported in 1911 in which African men were charged with crimes of rape or attempted rape of white women but in none was the death penalty imposed (PRO/CO $417 / 511$ no. 311. Rape Statistics, Southern Rhodesia. 1911 returns). Of the 32 cases dealt with in court during the first half of 1912, 2 concerned alleged rape of white women, 6 of white children under twelve years, and the rest concerned rape of African women; no death sentences were passed (PRO/CO 417/512 no. 465. Rape Statistics, Southern Rhodesia. 1912 returns). There were 59 incidents reported for all races in 1916, 54 in 1917, and 52 in 1918. No death sentences were passed in any of these cases, the majority of which involved Africans rather than whites. Most of the African men who were convicted and given varying sentences were found guilty of assaults with the attempt to commit rape (PRO/CO 417/617. Rape Statistics, Southern Rhodesia. 1918 returns). Rape statistics may have been collected beyond the years for which I have been able to find statistics.

55. In South Africa, the Immorality Act of 1927 outlawed sexual intercourse between whites and Africans. Marriage between whites and all nonwhites was outlawed in 1949 under the Prohibition of Mixed Marriages Act. In 1950 and 1957 the Immorality Act of 1927 was 
letters to newspaper editors in the wake of "the social scare" signed by Mrs. Robert Crawford Hawkin (Marie Botha Hawkin), sister of General Botha: "I have often heard strangers to South Africa express wonderment at the rigour of our authority over the blacks. They do not realize that if white men with their women are to live in a black country they can do so only as masters." 56 Some of these letters called for the recruitment of African women into domestic service to avoid problems between African menservants and their white madams. In 1905 a report was compiled on the issue by the South African Native Affairs Commission, which recommended promoting the employment of African women domestics. ${ }^{57}$ Yet, till the 1930s, most domestic servants on the Rand were men, whereas at the Cape more women, especially coloureds, were working in this occupation. ${ }^{58}$ And in 1930 in Southern Rhodesia, the premier suggested and the legislative assembly requested a commission to inquire into the question of employing African women as servants. Its report did not support the suggestion. ${ }^{59}$ The Federation of Women's Institutes of Southern Rhodesia had in the late 1920 s conducted a survey of white attitudes to African women domestics, submitting a memorandum about their findings to the premier and suggesting that he appoint the above-mentioned committee. Among those who supplied information was the widow of a BSAC administrator, Mrs. E. Tawsee Jollie, a well-known author and the first woman elected to the legislative assembly. She objected to employing men in service because of the "black peril" threat. But aside from herself, she told the FWI, only missionaries employed servant girls in Southern Rhodesia. 60

In 1910, in the charged atmosphere characterized by angry outcries about the Umtali case, High Commissioner Lord Gladstone commented on the suggestion to recruit African women as servants: "female domestic

amended to prohibit intercourse between whites and all nonwhite groups. These laws persisted till 1985. Legislation about immorality and intermarriage was instituted in Southern Rhodesia in 1903 in the Immorality Suppression Ordinance, by which a white woman convicted of illicit intercourse with an African might be sentenced to two years of hard labor, and the African to five years. An act of $\mathbf{1 9 1 6}$ made it an offense for a white woman to make indecent suggestions to an African man and for an African man to make such overtures to a white woman; but such behavior was not criminal between a white man and an African woman. For discussion, see Mason, Birth of a Dilemma, pp. 238-253.

56. NAZIM/S 144/4. BSAC Administration. "The Umtali Case." Newspaper clippings, letters to the editor, 1911.

57. Cited in Deborah Gaitskell, “'Christian Compounds for Girls': Church Hostels for African Women in Johannesburg, 1907-1970,"Journal of Southern African Studies 6 (1979): 45.

58. Deborah Gaitskell et al., "Race, Class, and Gender: Domestic Workers in South Africa," Review of African Political Economy 27/28 (1984): 86-108.

59. NAZIM/S 1561/48. Female Domestic Labour. Labour Memoranda and Minutes, 1941-1947. Report on Native Female Domestic Service. November 17, 1932.

60. Ibid. Report of the Standing Committee on Domestic Service by the Federation of Women's Institutes of Southern Rhodesia, pp. 63-64. 


\section{A Fixture of Colonial Society}

servants are not a practical possibility till the Matabele and Mashonas advance sufficiently to see that their women are better employed thus than in doing most of the hard labour . . . on the land." 61 To these comments he annexed a short memorandum, "[The] Native Servant Problem," in which he referred to practical difficulties and argued that the suggestion was "utterly opposed to native sentiment: a native, asked to allow his daughter to be trained in the service of a European Lady, would view the matter in much the same way as an Essex farmer would a proposal that his daughter should proceed to London to enter service as a coachman or chauffeur." $\mathrm{He}$ concluded that women in Rhodesia, for a long time to come, would have to be served by males, meaning "very small boys, seldom over the age of 12 and often much younger." 62

Among the practical difficulties the high commissioner alluded to was the "white peril": the reversal of the sex and race relationship which exposed African women to sexual advances and/or attacks by white men. A few of the letters mentioned the "white peril" and that African women had no way of saying no when approached by their masters. "We may not forget," noted a writer in a Southern Rhodesian newspaper in 1911, "that from the side of the native there is a White Peril. It is common knowledge that in these parts native women are not immune to the attentions of men, whose skins may be white, but who are white men in no other senses."63 The same year one reader wrote to one of the South African papers: "Thousands of young natives and coloured women are seduced by white men. . . . I believe the crime of a white man in seducing a native girl to be quite as great as rape committed by a black man upon a white woman. "64

If, pace van Onselen, "black peril" scares are central to understanding the white attitudes and ideology that structured race relations in South Africa, and, we may add, Southern Rhodesia, then their absence from Northern Rhodesia was a result of a very different climate of opinion. Richard Gray made this suggestion and included Nyasaland, from where at the time of his writing in 1960 not one case of rape of a white woman by a black man was recorded. Comparing and contrasting the racial policies of the south and the north, he noted that the situation in Nyasaland was less conducive to sexual hysteria since most whites there thought of themselves as paternal trustees. But in Northern Rhodesia policy ideas clashed, for the settler segment of the white population wanted to create another white

61. PRO/CO 417/496 no. 142. Case of Alukuleta. Memorandum by High Commissioner Lord Gladstone. March 29, 1911, p. 99.

62. Ibid., p. 100.

63. NAZIM/S 144/5. BSAC Administration. "Black Peril." Newspaper clippings.

64. Ibid. 
man's country as in the south, while white colonial officials called for a liberal interpretation of paternal trusteeship. ${ }^{65}$

Gray's reading of Northern Rhodesian historical records is somewhat misleading. For there had indeed been cases of rape of white women by black men during the period he refers to. They were, however, very few in number and; unlike in the south, they did not give rise to collective hysteria. While Gray is correct in stating, not that none, but that very few "black peril cases" have been brought to light from Northern Rhodesia, he is so for the wrong reasons. His explanation telescopes political ideologies that belong to the era of the 1930s and after. But during the period in question, that is, from the turn of the century through World War I, Northern Rhodesia was very much influenced by the south, economically as well as politically. The absence of the "black peril" scare in Northern Rhodesia had less to do with politics and economics than with sexual assumptions and demography in this much later and unevenly settled, and fitfully administered, part of the subcontinent. There were as yet few white women in Northern Rhodesia. When the Colonial Office took over its administration in 1924 , it was still very much man's country. The sexual anxiety here continued to center on African women.

The different texturing of the sexual aspect of the system of race relations in the north and the south was acknowledged in the regional discourse in several ways. Cullen Gouldsbury, a BSAC official in Northern Rhodesia from 1908, had been employed in Southern Rhodesia from 1902. A prolific writer of prose and poetry, his 1907 novel God's Outpost, set in Southern Rhodesia, caused a stir among the local whites and was withdrawn from circulation, apparently by the BSAC. ${ }^{66}$ In it, Gouldsbury allowed local gossip to construe as sexual the relationship between a white male missionary and a young Shona woman. This affair might have been too much for the class- and race-conscious Southern Rhodesians, and the suggestion has been made that the publication of the book was the reason for Gouldsbury's transfer to the remote north. ${ }^{67}$ Best-selling Southern Rhodesian author Gertrude Page wrote several novels but only one deals with interracial sex-and in it, significantly, she situates her plot in Northern, not Southern, Rhodesia. Her Silent Rancher is in all likelihood the novel that Acting Administrator L. A. Wallace referred to in his correspondence with the high commissioner in South Africa on concubinage. Page's brother was a

65. Richard Gray, The Two Nations: Aspects of the Development of Race Relations in the Rhodesias and Nyasaland (London: Oxford University Press, 1960), pp. 181-194.

66. Publisher's introduction to Cullen Gouldsbury, Rhodesian Rhymes (Bulawayo: Books of Rhodesia, 1969), p. 6

67. Anthony John Chennels, "Settler Myths and the Southern Rhodesian Novel" (Ph.D. diss., University of Zimbabwe, 1982), mentions this, p. $418 \mathrm{n} .23$. 


\section{A Fixture of Colonial Society}

farmer at Fort Jameson from whom she was likely to have had firsthand accounts of the local scene. ${ }^{68}$ The "black harem" of the administrator in her book was common knowledge, and it was brought to his prospective white bride's attention during her ship passage. The woman passenger who breaks the news feels that "the mere idea [of miscegenation] outrages the white woman," and that it is "a grave evil menacing [the country's] future." When she informs the prospective bride about the matter, she explains to her that many white women overlook their husband's sexual habits. "They have very little choice. Some do not mind. It hits you harder . . . because ... you are naturally so ideal . . . and unsophisticated."69

Although the northern whites heard about the southern "black peril" hysteria, they did not share it. They read the newspapers from the south, and from 1906 the Livingstone Mail provided extensive commentaries on the situation. According to my own reading, a total of seven "black peril" cases were commented on in the press between 1906 and 1931, ${ }^{70}$ and the newspaper's editor took particular pains to stress their rarity. In his response to a letter to the editor, for example, he noted that the writer's "reference to 'Black Peril' cases suggests that they are common, whereas we know they are not."71

The editorial commentaries explain the difference between Northern Rhodesia and the countries to the south by referring to the presence in South Africa of "riff-raff," that is, working-class whites who did not know what proper standards were and allowed themselves to be taken advantage of, and to half-educated African servants who did not keep their place. Northerners did not always agree with the outcome of the legal cases in the south. For example, Sam Lewis from Bulawayo was brought to trial for shooting his African servant Titus, who was alleged to have made indecent

68. Ibid.

69. Gertrude Page, The Silent Rancher (London: Hurst and Blackett, 1909), pp. 272, 282.

70. The first case, heard in court in March 1911, involved an African servant charged with burglary and the intent to commit rape of a white woman in Livingstone. He received six month' hard labor and 20 strokes with the cane: Livingstone Mail, March 4 (1911), p. 10, and September 16 (1911), p. 4. A case in Livingstone in 1914 concerned an African servant charged with intent to commit rape of a railway ganger's sixteen-and-a-half-year-old daughter. He was sentenced to five years' hard labor during which he was to be "treated like a savage beast," and given 24 lashes of the cane: Livingstone Mail, March 20 (1914), p. 3, and March 27 (1914), p. 7. A kitchen boy at the North Western Hotel in Livingstone was taken to court for having entered the bedrom of a white woman guest with the intent to commit rape in 1924. He got five years' hard labor and 24 lashes of the cane: Livingstone Mail, April 19(1923), p. 4. In Broken Hill in 1924 a houseboy was taken to court for having hidden himself in the closet of a fourteen-year-old white girl: Livingstone Mail, November 13 (1924), p. 4. Another case was reported in 1925: Livingstone Mail, February 26 (1925), p. 7, and two were brought to court during 193l, one involving an alleged attack by an African servant of a white woman in bed: Livingstone Mail, August 26 (1931), p.10, and one an indecent assault, involving an African servant charged with molesting a white child: Livingstone Mail September 23 (1931), p. 3.

71. Livingstone Mail, February 26, 1925, p. 7. 


\section{Women for Hire? Sex and Gender in Domestic Service}

overtures to Lewis's daughter. Although the shooting took place long after the incident, Lewis was acquitted by the white jury. In the north, according to the editor of the Livingstone Mail, while making "allowance for the abnormal conditions in [Southern] Rhodesia, the general opinion seems to be that the acquittal was a miscarriage of justice." 72

The difference between the north and the south is delineated by other writers as well. G. Heaton Nicholls, later a famous political figure in South Africa, was employed by the BSAC in Northern Rhodesia from 1902 to 1907, first as a member of the police force to train the Barotse native constabulary and later as a district officer headquartered at Mumbwa. ${ }^{73} \mathrm{His}$ novel Bayete! "Hail to the King"!, written in South Africa in 1915, draws on some of his experiences in the north and involves (in a sensationalist plot) a case of "black peril" in South Africa. In the course of the narrative, one of his protagonists comments: "no case has occurred in native areas where white women are leading lonely lives in perfect safety amidst a teeming native population. The crimes are the product of our cities . . . and are the result of our indiscretions, not to put it more mildly." His visitor, stationed north of the Zambezi, agrees with him: "The White women in Zambezia are treated with the utmost respect by natives. . . in their wild state they respect the whites. "74 Cullen Gouldsbury is one of several writers who echo this sentiment. He described how he would leave his wife by herself at night, with some askaris around the boma to be sure, when he was away on ulendo. To do so would be impossible, he contended, in civilized South Africa. But in the north, "a native would as soon purloin the offerings of flour from his village god's hut or the trinkets of beads from his brother's grave as attempt a criminal assault upon a white woman. "75

According to these texts white women householders in Northern Rhodesia commonly employed African menservants without much ado about sex. They used the language of culture and difference rather than of sexual fear to speak of their concerns and problems with African menservants. Although some incidents of "black peril" took place during later years, they were shaped by different forces from those in the south. ${ }^{76}$ But during the period preceding Colonial Office administration very few such cases oc-

72. "Sam Lewis Case," Livingstone Mail, August 19, 1911, p. 6, and "The Sam Lewis Case," Livingstone Mail, August 26, 1911, p. 7.

73. G. Heaton Nicholls, South Africa in My Time (London: Allen and Unwin, 1961), pp. 43-67.

74. G. Heaton Nicholls, Bayete! "Hail to the King"! (London: Allen and Unwin, 1923).

75. Cullen Gouldsbury, An African Year (London: Edward Arnold, 1912), pp. 70-71. See also, Owen Letcher, Big Game Hunting in North-Eastern Rhodesia (London: John Long, 1911), p. 231.

76. The incidents referred to by Gray, Two Nations, were described in the unpublished evidence given to the Royal Commission on Rhodesia and Nyasaland, 1938, the so-called Bledisloe Commission. 


\section{A Fixture of Colonial Society}

curred. That the sexual anxiety in Northern Rhodesia at this time revolved around African women can to some extent be explained by such demographic factors as the white population's disparate sex ratio and some white men's using African women to fulfill their sexual desires. Further, the system of contract migrant male labor may explain why white women chose African men for their domestic servants, since according to that system, African women were supposed to remain in the villages. Yet there were loopholes in the system, and African women did migrate to the towns from early on. If African women were available for sporadic sexual contact or prolonged cohabitation with white and African men in towns, they certainly formed part of the potential labor supply from which white women could have recruited their servants. What demography and the migrant labor system do not explain, then, is the sexual image of the African woman which was constructed in the white mind and provoked anxiety in white women's mind.

\section{Images of African Women}

African women's sexuality is a well-worked theme in the literature. ${ }^{77}$ To be sure, the image of African women which I derive from reading texts from the period of early white settlement in Northern Rhodesia is fairly similar to that painted by sources from other parts of Africa: the black woman as a creature of exaggerated sensuality, almost animallike, hot blooded, precocious, of "easy virtue." But although the theme is widespread throughout the continent, its constituent elements were combined in a variety of ways in different regions, and the resulting permutations are far from incidental. In Northern Rhodesia, the piecing together of disparate impressions about African women produced a discourse that accentuated their sexuality much more dramatically than was the case in the countries to the south. The Southern Rhodesian literature also depicts African women as immoral, but their immorality is far less essential and pervasive than it is seen to be in the north. ${ }^{78}$ As I suggested earlier, it was this image

77. See Philip Curtin, The Image of Africa: British Ideas and Action, 1780-1850 (Madison: University of Wisconsin Press, 1964), p. 216; Dorothy Hammond and Alta Jablow, The Africa That Never Was: Four Centuries of British Writing about Africa (New York: Twayne Publishers, 1970), pp. 148-156; and Winthrop D. Jordan, White over Black: American Attitudes toward the Negro, 1550-1812 (Baltimore: Penquin Books, 1971), pp. 32-40.

78. For early studies from Southern Rhodesia, see D. Carnegie, Among the Matabele (London: Religious Tract Society, 1894; reprint, Westport, Conn.: Negro Universities Press, 1970), and F. W. T. Posselt, Fact and Fiction: A Short Account of the Natives of Southern Rhodesia (1935; facsimile reprint, Bulawayo: Books of Rhodesia, 1978). Among later studies, see W. Bazeley, "Manyika Headwomen," NADA 17 (1940): 3-5; H. C. Childs, "Family and Tribal Structure and the Status of Women," NADA 35 (1958): 65-70; Michael Gelfand, African Crucible: An Ethno-Religious Study with Special Reference to the Shona-Speaking 
of the "oversexed" African woman which fostered anxiety among the northern whites about the "white peril" while their southern neighbors feared the black.

This image arose from whites' reactions to the African societies they encountered in Northern Rhodesia, and in particular from whites' perception of these Africans' social organization, kinship and marriage practicestheir flexible marriage arrangements, polygyny, polyandry and matrilinyas manifestations of immorality. The commonality of the two latter practices distinguished Northern Rhodesia from its southern neighbors. ${ }^{79}$

What sources were available up through the 1920 s to inform local whites about the societies in the middle of which they lived? There were "ethnographies" consisting of the observations made by missionaries and administrators; there was a prolific travel literature; and there were more detailed memoirs and autobiography. This literature has been used by scholars for a variety of purposes. ${ }^{80}$ Here I offer but a few glimpses of the white discourse about local African sexual mores, an issue not distilled out and dealt with in the works most usually referred to.

The Ila, for example, a cattle holding, fishing, and horticultural society on the Kafue flats, received "bad press" from the early days. William Chapman, a missionary of the Primitive Methodist society who had worked in their region since 1905, wrote in 1911: "[they] are a people whose national business is polygyny, their national pastime beer drinking, and their national sport fornication." 81 J. H. Venning spent time at Kalomo during World War I. In his memoirs of life in Northern Rhodesia from 1893 to 1962 , he described the Ila as the "most immoral tribe in the country, but

People (Cape Town, 1960), and also his "The Shona Attitude to Sex Behavior," NADA 9 (1967): 61-64.

79. Matriliny and polyandry were also widespread in the neighboring country to the north, the Congo, and some of the points I make about African women and sexuality may perhaps apply there as well. Because the countries to the south provided the reference point for contrasts and comparisons when white Northern Rhodesians discussed labor policy and native administration, I have not explored the discourse on sex in texts from the Congo in any detail. In the Congo, African men dominated in domestic service. White women, commented an observer of household relations in the capital in the mid-1940s: "generally prefer . . . to be served by men or boy servants. [They] have one hundred good reasons to prove that it is not preference but sheer necessity, the most obvious being that men are already trained to do that kind of work. . . . At the bottom of their dislike for women servants . . is the underlying fear of the attraction of the black woman for the European man." Suzanne Comhaire-Sylvain, "Food and Leisure among African Youth of Leopoldville (Belgian Congo)," University of Cape Town, Communications from the School of African Studies, new series no. 25 (1950), p. 54.

80. Cairns, Prelude, delineates British reactions to Central African society in the half decade preceding the imposition of BSAC rule from 1840 to 1890 . Rotberg, Christian Missionaries, details the role of missionaries in "opening up" Northern Rhodesia over the period leading to direct colonial rule in 1924. Macpherson, Anatomy, has added Zambian sources to demonstrate the coercive nature of the conquest.

81. Cited in Rotberg, Christian Missionaries, p. 40. 


\section{A Fixture of Colonial Society}

one should rather call them amoral ... [for they] seemed devoid of any moral code in matters of sex." 82 In Edwin Smith and Andrew Dale's twovolume ethnography from 1920 , the discourse is much the same. The authors, a missionary and a BSAC magistrate begin their chapter about relations between the sexes with this effusion of offense at their subject:

there is much that is unpleasant in this part of our subject. [But] to write of the Ba-Ila and omit all reference to sex would be like writing of the sky and leaving out the sun; for sex is the most pervasive element of their life. It is the atmosphere into which children are brought. Their early years are largely a preparation for the sexual function; during the years of maturity it is their most ardent pursuit, and old age is spent in vain and disappointing endeavours to continue it. Sex overtones all else. ... To them, the union of the sexes is on the same plane as eating and drinking, to be indulged in without stint on every possible occasion. ${ }^{83}$

Dale and Smith also noted that while men and women might indulge their sexual instincts, they must respect proprietary rights. A woman's sexuality was her husband's property; he might give a friend this right just like he might offer a meal; but if the friend took without permission he might be fined. "It is," they stated, "a matter of property, not moral reprobation." 84

According to Dale and Smith, all Ila men wished to marry early and to have as many wives as possible, some of whom were slaves who lived as concubines. The Ila also practiced a type of polyandry in which husbands allowed their wives to live with lovers for a shorter or longer period. Adultery was rampant, and, moreover, Ila wives often would "go and prostitute themselves" after making agreement with their husbands, who in turn claimed damages for adultery. ${ }^{85}$ The reviewer of Dale and Smith's book was at a loss for words: "this is not for family reading; . . . some portions have been done into Latin, the better to conceal them. . . . Of their sex relations it is impossible to speak here; they are, to a European thinking man, one mass of obscenity." 86

Dale and Smith were not alone in commenting on polyandry; it was assumed to be widespread. Stephenson discussed its practice among the Lala. ${ }^{87}$ Brelsford, who was stationed at Mumbwa in Ila country in the early 1930s, published a paper on Lubambo, a type of polyandry, in an anthropo-

82. J. H. Venning, "Memories of My Life in Southern Africa, from 1893 to 1962," unpublished papers deposited at Rhodes House, MSS Afr. S. 1490, p. 121.

83. Edwin W. Smith and Andrew Dale, The Ila-Speaking Peoples of Northern Rhodesia (London: MacMillan, 1920), p. 35.

84. Ibid., pp. 35-36.

85. Ibid., pp. $64,67-69,72-73$.

86. "Review of The Ila-Speaking Peoples of Northern Rhodesia," Livingstone Mail, December 2 (1920), p. 6

87. Stephenson, Chirupula's Tale, pp. 46, 231. 
logical journal. ${ }^{88}$ Dugal Campbell, who lived in various parts of this territory for twenty-nine years around the turn of the century as a missionary and later a labor recruiter for the Katanga mines, noted in his "ethnography" that polyandry was common in Central Africa among the Bemba, the Lunda, the Luba, and among the Luena of Angola. ${ }^{89}$ In later years, during the 1950s, the "loose morals" of Congolese Kasai women on the copperbelt were attributed to their polyandrous background. 90

Matriliny, the organizing principle of the majority of the African societies within this region, was also seen as predisposing African women toward immorality. J. M. Moubray, a mining engineer who traveled throughout the territory between 1903 and 1908 commented in this regard: "In Central Africa the morals of many tribes are somewhat lax. It is a mistake to suppose that uncivilised people are generally very moral, this being often the exception than otherwise. This laxity as regards the moral code is recognised to such an extent among many of the tribes that, instead of inheritance passing from father to son, as in European countries, it passes from father to sister's son." 91

The image of the sexually free, morally lax African affronted the late Victorian/early Edwardian British ideals and the assumption that sex was to be contained within the conjugal bond. ${ }^{92}$ The contrast between turn-ofthe-century British social norms and what was considered to be a wild, primitive, and sexually permissive environment can be seen to have prompted extreme but different reactions in white men and white women. White men may have regarded African women as an outlet for sexual experiences outside those available in the conventional conjugal relationship and may thus have been sexually attracted, whereas white women's reaction may have combined disgust and envy. Among most African societies in this region, young girls were taught quite explicitly during initia-

88. Vernon Brelsford, "Lubambo: A Description of the Baila Custom," Journal of the Royal Anthropological Society of Great Britain and Ireland 63 (1933): 433-439.

89. Campbell, In the Heart, pp. 163-164.

90. John Taylor and Dorothea Lehmann, Christians of the Copperbelt: The Growth of the Church in Northern Rhodesia (London: SMC Press, 1961), p. 73, and Dorothea Lehmann, "Marriage, Divorce, and Prostitution of African Women in a Changing Society," in Report of the Annual Conference of the Northern Rhodesia Council of Social Service on Marriage and the Family (Lusaka: Government Printer, 1961), p. 34. For an ethnographic account, see Mary [Douglas] Tew, "A Form of Polyandry among the Lele of the Kasai," Africa 21 (1951): $1-12$.

91. J. M. Moubray, In Central Africa (London: Constable 1912), p. 69.

92. This ideal and its changes are described by Lawrence Stone, The Family, Sex, and Marriage in England, 1500-1800 (New York: Harper and Row, 1979). On sexual attitudes, see Eric Trudgill, Madonnas and Magdalens: The Origins and Development of Victorian Sexual Attitudes (New York: Holmes and Meier, 1976), and Peter Gay, who qualifies these observations in many respects in The Bourgeois Experience: Victoria to Freud, vol. I, Education of the Senses, and vol. 2, The Tender Passion (New York: Oxford University Press, 1984 and 1986). 


\section{A Fixture of Colonial Society}

tion rites how to perform sex and how to please partners. ${ }^{93}$ White women's perceptions of African women's sexuality exacerbated their sense of being different and strengthened the need to keep African women out of the colonial household. To lessen sexual anxiety, social distance from African women had to be maintained — by both men and women, as Hammond and Jablow have noted: “an Englishman neither marries, employs, nor befriends an African woman. The only possibility is a sub rosa offer, making sexuality the only basis for any relationship at all."94

The question of whether the condition of moral laxity existed before contact with whites or was its result was rarely addressed in the literature. One exception is worth noting. It concerns the Lamba, who lived in the area that later developed into the copperbelt. Lamba women were depicted as "champions" among prostitutes during the period of the copperbelt's rapid growth and, much like the Ila, inherently immoral.95 But Clement M. Doke, a missionary in the Lamba region from 1914 to 1921 , in a 1931 monograph tempered the prevailing view with an analysis that vested responsibility with the Europeans: "exaggerated statements have often been made concerning the looseness of the natives of Central Africa. . . . It must be remembered that in these days the introduction of European customs and mode of life, with all the contacts which that means, has undermined tribal control, throwing the social fabric into the melting pot. There are not now those restraints which were potent a few years ago, with the result that today there is certainly a tendency to moral looseness. But we cannot put this down to Lamba social organization, which is definitely opposed to moral laxity. "96 Most whites, however, continued to view African women's "loose morals" as the result of tribal practices. Immorality was a primordial attribute, and African women were therefore dangerous.

\section{Bachelor Towns and the Immorality Issue}

The authorities' attempts-no matter how ineffective-to restrict and control African women's movements between villages and towns bear evidence that the image of moral laxity and promiscuity formed during the

93. Audrey I. Richards, Chisungu: A Girl's Initiation Ceremony among the Bemba of Zambia (London: Faber and Faber, 1951), C. M. N. White, "Elements in Luvale Beliefs and Rituals," Rhodes-Livingstone Papers, no. 32 (1961); and V. W. Turner, The Drums of Affliction: A Study of Religious Processes among the Ndembu of Zambia (Oxford: Clarendon Press, 1968).

94. Hammond and Jablow, Africa That Never Was, p. 153.

95. Brian Siegel, "The 'Wild' and 'Lazy' Lamba: Ethnic Stigmatization and Resentment on the Central African Copperbelt," paper presented to the International Conference on History of Ethnic Awareness in South Africa, Charlotteville, N.C. April 7-10, 1983.

96. Clement M. Doke, The Lambas of Northern Rhodesia: A Study of Their Customs and Beliefs (London: Harrap, 1931), p. 158. 
early decades of contact continued to be the operative one in later years. A slight shift in nuance occurred, however, as immorality and promiscuity came increasingly to mean prostitution.

The Ila of Mumbwa subdistrict had already been the subject of much invective concerning sexual matters. Referring to Ila women who had gone off to the line-of-rail towns, Native Commissioner J. W. Sharrat-Home cried out in 1923: "We want the women sent back. In what way will the law assist us?"97 Because of their laxity in sexual matters, "those who know them best regard the Baila, mainly through this course, as a dying race. ... the people themselves are largely responsible. . . free love may be said to be paramount throughout the district." 98 This particular concern about the Ila had arisen because of the poor health, venereal disease, lack of children, and absence of married women and girls noted by officers on tour in the subdistrict. Bringing these observations to the district commissioner's attention, the native commissioner reminded him:

the Baila (so we learn from the official handbook of the territory) are "chiefly noted for their low state of morality" . . . [and these] remarks [are] not much out of place if applied to the Balenje or Balovale. . . Morally the sub-district has probably never reached a very high standard, [and] it might now be called the brothel of Northern Rhodesia. . . . Since the advent of civilization and its new standards of wealth for the natives-money, calico, blankets, butcher's meat, and the excitement of compound life-the outward and visible rewards of immorality have become much greater, and women of the sub-district have not been slow to take advantage of the inducements offered. ${ }^{99}$

According to this native commissioner, local Africans first were introduced to these articles of wealth some ten to fifteen years earlier when small mines operated in the region. Nonlocal Africans were brought in to work them; when the mines were closed down, these workers took Ila women with them to the towns. Since then, many unmarried women had begun to "gravitate towards the life of comparative luxury and ease to be secured by selling their bodies to any native wealthy enough. . . . During the past ten years the number of women leaving the district has increased enormously and to-day they are to be counted in hundreds." 100

97. NAZ/BS 3/303. Prostitution and Temporary Unions of Women of Mumbwa SubDistrict in Settled Areas, 1923-1924. Native Commissioner, Mumbwa, to District Commissioner and Magistrate, Mumbwa. February 18, 1923.

98. Ibid. District Commissioner and Magistrate, Mumbwa, to Secretary for Native Affairs, Livingstone. March 4, 1923.

99. Ibid. Native Commissioner at Mumbwa to District Commissioner and Magistrate, Mumbwa, February 18, 1923.

100. Ibid. 


\section{A Fixture of Colonial Society}

This official once again ascribed the problems with the Ila to "the looseness of the marriage tie among the natives, and the looseness of their ideas as to what constitutes marriage." According to his observations, there were three ways of forming unions: a nonlocal African man might buy a girl from her Ila family; a woman might make an agreement with a man to live with him as a concubine "and receive clothing and other presents" for her services; and, there was prostitution, "pure and simple . . in the narrow sense of the word." Among the prostitutes were unmarried women elders brought out of the district for the purpose of procuration. The official knew three such cases, plus many stories about real trafficking: "I have heard of one case where a woman who had been living with an alien in Livingstone came home and stayed a month or two, and then returned to Livingstone with six unmarried girls ... [and] of a certain man in the north of the district who makes periodic pilgrimages to the Lubumbashi mine [in the Congo], never with less than 4 or 5 girls." He held that such trafficking took place because aliens wanted and were willing to pay for concubines; women wanted clothes and had no moral compunction about how to get them; and their fathers, usually not approving, were not strong enough to resist the sight of money. And, finally, because an African worker, separated from his rural wife, "being a sensual animal, demands some temporary accommodation. . . . This demand local women do their best to supply."101

Colonial male officials ascribed African men's desire for female company solely to their sexual needs; because African women supposedly lacked moral scruples, they readily supplied their services. While they might not be "common prostitutes or streetwalkers," once they came to town, there was little "to prevent them from whoring." Such were the opinions of Magistrate Melland, who raised the issue of controlling women's movements "in view of the unsettling effect in the district of a life of prostitution being lived by hundreds of native women; the spread of veneral disease, and especially of the infection of young girls."102 In a circular letter to the officers in his area he related how he had attempted to reduce the traffic in women in the Kasempa district, by allowing Kasempa headmen to prohibit women and girls from going to towns if they were suspected of prostitution. Women who disobeyed were arrested and fined; some were imprisoned without the option of a fine. Melland suggested that this approach might be successful elsewhere and was advised by the secretary for native affairs that the following orders were likely to be considered reasonable: "a) no unmarried woman or married woman unaccompanied by her husband shall leave the district without permission from the Native Commissioner; b) natives

101. Ibid.

102. Ibid. District circular letter from District Commissioner and Magistrate, Mumbwa. July $7,1923$. 


\section{Women for Hire? Sex and Gender in Domestic Service}

of other districts wishing to marry local women must come before the Native Commissioner and satisfy him that Native Custom has been satisfied. No alien must take a woman out of the district without proving to the satisfaction of the Native Commissioner that she is his lawful wife." 103

High Court Judge P. J. Macdonnell, however, criticized the circular letter as well as the order. He doubted that it could "be considered a general lawful order that women are not to go to the [towns] for any purpose." Furthermore, the judge noted, the circular letter did not distinguish between prostitution and concubinage; its remarks implied that a person would be found guilty unless she proved her innocence. Such an order would give the "headmen too autocratic powers and curtail people's liberties." Under colonial law, headmen had local not personal power. The legal advisor suggested that Magistrate Melland had been misled about the powers of headmen and pointed out that Melland, qua judge, had no legislative but purely judicial powers: a judge "administers; he doesn't make the law."104

Melland disagreed. In reasoning why headmen ought to be allowed to prevent women from going to towns for any purpose, he had cited his own judgment of a court case concerning a woman who had cohabited with a man at Bwana Mkubwa mine without permission of her parents or the headman. She had been ordered off the compound premises, yet she had returned, and the mine authorities sent the case to the boma. Although the man promised to marry her and the parents approved their union, Melland could not see that these circumstances "acquitted her of having lived an immoral life at Bwana Mkubwa mine in defiance of lawful order." The native commissioner at Ndola set her free, but Melland would have convicted her. ${ }^{105}$

Commenting on the legal advisor's opinion, Magistrate Melland explained his position: "I appreciated the difference between concubinage and prostitution, [yet] I considered the line too fine. . . . Natives have only one word 'marry' for marrying a woman, or taking her as a mistress or concubine; the women who come to Broken Hill and other [towns] for the purpose referred to do not use this word, they do not say they come here 'to marry,' but use the word-kusebenza-'to work' . . . which I have

103. Ibid. Secretary for Native Affairs to District Commissioner and Magistrate, Mumbwa. July $17,1923$.

104. Ibid. Judge Macdonnel to Registrar, Livingstone. October 25, 1923. Legal Advisor to Secretary for Native Affairs, Livingstone. December 1, 1923.

105. Ibid. Annex to circular letter (see note 117). Native Commissioner, Ndola, Criminal Case No. 71 of 1923. May 12, 1923. This may be the case referred to by Helmuth Heisler, Urbanisation and the Government of Migration (New York: St. Martin's Press, 1974), p. 69, about the1924 quashing of a conviction of a woman found guilty of disobeying an order issued under Proclamation 8 of 1916 from Mumbwa subdistrict. My sources date the event to 1923. 


\section{A Fixture of Colonial Society}

taken to mean to follow the profession of prostitutes."106 Melland did withdraw his circular letter, noting that the ruling was "from an administrative aspect, a severe blow to me. . . . I am always telling [the Africans] that we stand behind them in maintaining their customs (with certain exceptions) and I have tried to live up to this."107

During the last year of the BSAC administration, the secretary for native affairs at Livingstone commented to the district commissioner at Fort Jameson, who was concerned about the exodus of women, that "the problem of restricting immorality by legislation is a thorny one but some action seems desirable in the interests of the native population." 108 His view was shared by many, but the problem of implementing legislation stemmed in part from colonial officials' interpretation of what was customary in terms of sexual relationships. The official legal stance was that custom should be maintained, within the limits of what whites considered to be morally acceptable. If prostitution were to be a matter for colonial law, it had to be part of the fabric of customary law and to be punishable within that framework. Officials cited section 15(11) of Proclamation 8 of 1916, which imposed on headmen the duty to "suppress . . . prostitution, procuration and all matrimonial or sexual relations contrary to custom of the tribe and harmful to the wellbeing of the village." Yet this formulation did not enable legal advisors to state definitively that the departure of women from tribal areas for purposes of prostitution constituted a criminal offense in the "natural customary law" of any given tribe - that is, a crime punishable by death or mutilation. If it was punishable merely by a fine, women's departure could not be regarded as a criminal offense under customary law. ${ }^{109}$

Despite the debate, no overall legal action was taken to restrict women's movements to towns in the 1920s. Rural native authorities were left to deal with the problem within the limits of their local powers, in other words, by proposing rules that, if accepted by the secretary for native affairs, became orders within their territories. If part of the problem was due to white officials' attempts to reinvent custom, 110 another part was due to the in-

106. Ibid. District Commissioner and Magistrate, Broken Hill, to Registrar, High Court in Livingstone. November 5, 1923.

107. Ibid.

108. Ibid. Secretary for Native Affairs, Livingstone to District Commissioner, Fort Jameson. September 27, 1923.

109. Ibid. Legal Advisor and Public Prosecutor's Office to Secretary for Native Affairs. December 20, 1923.

110. Martin Chanock and Marcia Wright have argued that white legal officials changed the law considerably when, during the early decades of colonial rule, they sought to identify and codify customary law, thus in fact making it. See Martin Chanock, "Making Customary Law: Men, Women, and Courts in Colonial Northern Rhodesia," and Marcia Wright, "Justice, Women, and the Legal Order in Abercorn, North-Eastern Rhodesia, 1897-1903," in Jean Hay and Marcia Wright, eds., African Women and the Law: Historical Perspectives (Boston: 
ability of the native authorities to stem the tide of migration to towns, not only of women but also of children and adult men. The problem all parties faced reflected their inability to cope with ongoing social and economic changes in the colony. These processes did not stop and the debates concerning women's migration to towns and prostitution and immorality continued, with a hiatus during the depression, till the post-World War II years. To set the stage for the subsequent reemergence of the immorality issue, we may do well to take note of the women's words: they had gone to town to work. If Melland was correct in interpreting work as prostitution, he did not adequately explain the economic circumstances that prompted it.

It was not inherent immorality, lack of moral compunction, or loose marriage ties that made women dispense their sexual services. The literature from the 1930s, 1940s, and 1950s shows that actually the extent to which they did so on a purely commercial basis was limited.111 Women made cohabitational and housekeeping arrangements with men, often without being legally married, because it was one of the very few ways in which they could ensure economic support in towns. The changing socioeconomic urban scene that left few wage labor options open to African women thus provided the context for the shifting focus in the official discourse from "immorality" to prostitution. The deteriorating rural socioeconomic conditions that had prompted women's migration to towns were obscured during the lean years of the 1920s and the poor years of the depression, when many African town dwellers were forced to return to the rural areas because of the lack of employment. But they were revealed once men returned to work in towns and mines and officials sought to reinstitute the old geographical division of labor by sex, separating men workers in towns and mines and women cultivators in the rural areas. When economic activity picked up momentum after the depression, authorities once again became concerned with the movement of women and children to the towns.

The mining companies did not share their concern. During the 1930s they had begun to encourage men to bring their families to live with them in the compounds in Luanshya and Broken Hill. The presence of wives who cooked and tended to their men's needs improved labor productivity without the companies' having to pay higher wages. George Chauncey has

\footnotetext{
African Studies Center, 1982), pp. 53-67, 33-50; also Martin Chanock, Law, Custom and Social Order: The Colonial Experience in Malawi and Zambia (Cambridge: Cambridge University Press, 1985).

111. See, for example, Godfrey Wilson, "An Essay on the Economics of Detribalisation in Northern Rhodesia, Part 2," Rhodes-Livingstone Papers, no. 6 (1942), pp. 66-69; Chauncey, "Locus of Reproduction"; and A. L. Epstein, Urbanization and Kinship: The Domestic Domain on the Copperbelt of Zambia, 1950-1956 (New York: Academic Press, 1981).
} 


\section{A Fixture of Colonial Society}

delineated the way in which mining capital in this instance benefited by the compound, not the village, being the locus of reproduction. ${ }^{112}$ The presence of children, especially boys, served a similar purpose. They did cleanup work in mines and compounds, worked in white households, and cooked, cleaned, and did laundry for single male migrant workers; they also did household chores for African miners' wives and garden work for those who had plots. ${ }^{113}$

Colonial and native authorities were alarmed at these developments, but not for the same reasons. Colonial authorities were concerned with the problems that were beginning to arise from the rapid growth of substantial African populations in the towns, which were not designed to house and service them. The officials also dreaded the consequences of detribalization in the rural areas, that is, the undermining of traditional authority. Responding to the chief secretary's call in $\mathbf{1 9 3 6}$ for an inquiry into the causes and effects of labor migration from the tribal areas, the native commissioner from the Central Province noted: "The source of the greatest harm is the wives who have accompanied [the men]. They have learned loose habits and are apt to refuse to carry out the normal household duties. . . . Another disadvantage is the gradual deterioration of the children who grow up under compound conditions." 114

Alarming comments came in from other regions. The district commissioner from Lusaka district noted that "the women in the compounds have virtually nothing to do. . . . With hours of idleness on their hands it is not surprising that they often fall from grace when strange men appear. . . . It is certain that in the town many married women are tempted to become common prostitutes." 115 The report from Broken Hill stressed a situation of chaos and wholesale immorality, the latter attributed as usual to loose marriage ties of intertribal unions. Many men who had left wives and families behind contracted temporary marriages after arrangements with parents or guardians, who "simply hired the girl out for profit." And from Mkushi district "one evil . . . is the desire of an appreciable number of women to share in the pleasures of town life, which upsets the [rural]

112. Chauncey, "Locus of Reproduction," p. 137.

113. Numerous examples of children's work in towns are given in the official correspondence. See, for example, NAZ/SEC 1/1316. Labour: Employment of Children, 1938-1945; NAZ/SEC 1/1350. Repatriation of Unmarried Women; and my own "Labor Migration and Urban Child Labor during the Colonial Period in Zambia," paper presented to the Conference on the Analysis of Census Data from Colonial Central Africa, University of Wisconsin at Milwaukee, August 18-22, 1986.

114. NAZ/SEC 1/1312. Administration of Native Labour. Investigation of Labour Conditions in Northern Rhodesia. Senior Provincial Commissioner, Central Province, Lusaka, to Chief Secretary. October 18, 1937.

115. Ibid. Report on the Causes and Effects of Native Labour Migration in the Broken Hill District. June 7, 1937, p. 15. 
menfolk a good deal. These women when arrived at the labour centres adopt whoring as a livelihood, or at least concubinage."116 Officials also worried about the large numbers of young boys above ten years of age who had gone to towns: "A youngster . . . almost invariably grows up to be a thoroughly bad character, but even when his sojourn is only for a few years or less, he naturally absorbs much that is evil." 117

From the point of view of the rural native authorities, there were two important concerns: the machona - the "lost ones," the men who had left, never to return-and the loose sexual habits of women in towns. But as more marriageable men disappeared to town, so did women. Perhaps understanding women's dilemma, the Mkushi local courts adopted the practice of granting divorces to women who had been deserted by their husbands and not received support for two years. And wives who received money or other support from absent husbands who did not return when called back after three years were also granted a divorce. ${ }^{118}$ Young rural women of marriageable age, divorcees, and widows unable to find husbands of their own choice were likely to become one of several wives of elderly men or remain single poor dependents of their aged parents or guardians. ${ }^{119}$

The reports stress collectively that prostitution and contempt for customary law and authority were the two most striking and dangerous results of town life. When women married or cohabited with men from other ethnic groups, rural native authorities lost their ability to control marriages. They were less likely to receive remittances from men who had married intertribally in town. And migrant workers who returned from town had seen a different world. Wanting perhaps to do things in new ways, they began to question the decisions of tribal authorities. As more young people went to towns and more children grew up urban areas, it became less likely that traditional mores would be imparted to the young generation, who then might lose respect for the old.

Acting out of these concerns, when the migration process quickened after the depression, rural native authorities began to call for official restrictions on women's and children's movements. And this time, unlike in the 1920 s, their pleas received a sympathetic hearing from colonial authorities. Over the following years, most native authorities passed orders prohibiting unmarried women, children, and wives unaccompanied by husbands from leaving their villages without permission of guardians, headmen, or chiefs. But the native authorities had few means of enforcing these orders, and so

116. Ibid. Report on Emigrant Labour, Mkushi District. 1937.

117. Ibid. Broken Hill District, p. 15.

118. Ibid. Mkushi District, p. 2.

119. Cliffe, "Labour Migration." 


\section{A Fixture of Colonial Society}

the exodus continued. Great trouble was taken to little avail. Patrols were placed along some of the major migration routes to check for women's permission papers. Transport companies that operated along these routes were requested to do the same. The African drivers easily circumvented these arrangements; they hid women in the lorries and gave them "a lift in exchange for their pleasant company on the journey; no money passes." 120

A bill was drafted in 1936 for the repatriation of natives from the urban areas, ${ }^{121}$ and the native authorities continued to try, with the colonial authorities' approval, to prevent women from leaving the villages and to collect them from towns once they had done so. Rural native authorities would sometimes send kapasus to town to round up women and children. Chiefs and headmen also paid occasional visits to towns for the same purpose and were sometimes assisted by the compound police. But many women and children did not remain in the villages for long, and the native authorities continued to be perturbed by the matter. Colonial authorities did little about the situation during World War II, but in 1944 they began to allow the Urban Native Courts, established in 1939, to issue marriage certificates to couples after receiving approval from the rural native authorities. Since this consent was often slow in coming, urban African couples frequently took matters in their own hands. By the close of the war, the question of women's right to live in towns had become more complicated.

There was lack of consensus among African men about whether women's proper place was rural or urban. The issue was often the topic of heated discussion in the newly created regional councils (or provisional councils, as they came to be called), which had been established in 1943, and comprised representatives of African rural and urban authorities. At a meeting in Ndola in 1945 of the African Provincial Council for the Western Province, for example, Adam Frog, a representative from Ndola, commented that when "the chiefs were asked why they had not looked after the women better they replied that they had no place to keep them, and that there were few men in the villages and the women just disappeared, they did not know how. They asked the Government to find a way of keeping women in the villages." Mwachande, from the Swahili native authority, argued that the "trouble was that the girls did leave the villages and the town dwellers gave them sugar and meat and all sorts of things. In the villages they get only bad food . . . and they did not like living there. When they were arrested and kept in the villages the town dwellers came and fetched them back again." But Dauti Yamba from Luanshya wondered "why the women

120. NAZ/SEC 1/1350. Repatriation of Unmarried Women from Industrial Areas, 1940 1949. Provincial Commissioner, Fort Jameson, to District Commissioner. June 25, 1940.

121. Heisler, Urbanisation, p. 99. 
were singled out. He thought the men were to blame too. . . . It could never be a happy village where there were no men and the women had to do everything with no man to help them. If the loafers were sent home they could settle down with the women in the villages." 122 At another council meeting for the Western Province held in Kitwe in 1945, the remarks of Esau Tembo were similar: "in my area . . . the people said that if boys are allowed to go to towns to work for Europeans, why cannot the girls also be allowed to go to towns. . . Sometimes these girls go to visit their relatives or friends and sometimes the people who look after them in towns are their own guardians. It was also said that if the girls are stopped from going to towns, it means that they are being put to prison, because today there are not many boys living in the villages who can help the girls." 123

At a 1946 meeting of the African Representative Council, formed that year, Nelson Nalumango from the Southern Province characterized "types" of women: "There is a married class and there is a class of working women and the third class is the class of undesirable women. . . Y You find them in Lusaka today and next day you find them on the copperbelt and by January you hear they are in Wankie [a coal mining town in Southern Rhodesia] and the week after they are in Livingstone and wherever they go they cause a lot of trouble. People fight over them . . . they are the people whom the government should compel to go back to the villages."124

Rural native authorities had only local power; they depended on the colonial authorities to effect changes in the movement of women and children. Such an effort was made in 1946 when the colonial government empowered Urban Native Courts to enforce rural native authority rules and to return women and children who had come to towns without permission. ${ }^{125}$ In this decision we can see how the official discourse was focused on the notion of prostitution; we can also see how the resulting negative image of African women shaped legal practices. But the protracted discussion that preceded the decision belied actual social practices in the changing colonial situation. At the time the decision was made, there were thousands of women and children in the towns, and repatriation orders

122. NAZ/SEC 1/1350. Repatriation, which includes a variety of minutes and extracts from meetings with African representation on which notes 123 through 125 below are based. Minutes of the African Provincial Council, Western Province, Meeting at Ndola. October 1945.

123. Extracts from Minutes of Meeting of the African Provincial Council, Western Province, at Kitwe. 1946.

124. Extracts from Minutes of First Session of the African Representative Council. November 1946.

125. Extracts from Minutes of Fifth Meeting of the African Provincial Council, Northern Province. April 1948. Comments by Secretary for Native Affairs. But see Heisler, Urbanisation, p. 99, who states that this policy was introduced in 1952. 
were difficult to enforce. Perhaps it was this reality that led the government in 1953 to authorize the Urban Native Courts to issue marriage certificates to African couples in towns without prior approval of rural native authorities.

\section{The Campaign for African Womanpower}

African women and children continued to be repatriated from towns to rural areas after World War II. Yet the outcry against their presence in towns seems to have abated, ${ }^{126}$ perhaps because wartime issues claimed the authorities' attention. Labor was scarce within the colony, and many African men served in the armed forces. The economy gained new momentum during the world war and the Korean War, when the copper industry boomed, secondary industries developed in munitions and autoparts, and the construction sector grew. Continued labor shortages throughout industry, government, and agriculture after the war invited new thinking on work and how to house workers.

In this situation of labor shortages, the colonial government formally adopted the mining companies' practice of providing some workers with family housing in order to reduce the rate of turnover and increase productivity. But their policy of "stabilization without urbanization" was halfhearted for it aimed at providing better housing for a small ratio of the African urban population rather than improving the standards of living for all. Africans were still not considered urbanized, their rural ties were not to be severed, and the great mass of the African urban working class continued to make their own work and housing arrangements.

The towns grew rapidly. Lusaka's African employed population increased almost six-fold from 1931 to 1946 and almost tripled, from 7,544 to 22,444 between 1946 and 1956 (see Table 4). ${ }^{127}$ Some of this growing population was accommodated in new housing, built after the 1948 passage of the African Housing Ordinance which enabled local authorities to build African suburbs with married quarters in addition to the usual hostels for bachelors. An African Housing Board was set up and in Lusaka two new municipal townships were begun, one of them the model African suburb, Chilenje. Several more townships were planned here as elsewhere, but not built. The territory's entry into the Central African Federation in 1953

126. This observation may be erroneous and a result of the lapse in publication of some of the colonial reports during the war.

127. Part of Lusaka's six-fold growth between 1931 and 1946 was probably due to the move of the capital from Livingstone to Lusaka in 1931. The 1931 and 1946 figures are taken from Report on the Census of the Population of Northern Rhodesia Held on 15th October, 1946 (Lusaka: Government Printer, 1949), table 2, p. 69, and the 1956 figures from Census of the Population, 1956, Federation of Rhodesia and Nyasaland (Salisbury: Central Statistical Office, 1960), table 80, p. 165 . 
Table 4. Number of Africans employed in urban areas of Zambia, by area, 1931, and by sex, 1946

\begin{tabular}{lrrrrr}
\hline & \multirow{2}{*}{\multicolumn{1}{c}{ Urban area }} & & \multicolumn{3}{c}{1946} \\
\cline { 5 - 6 } \cline { 5 - 6 } & Total & & Males & Females & Total \\
\hline Broken Hill Township & 2,441 & 2,890 & 69 & 2,959 \\
Broken Hill Mine Township & 2,318 & 3,286 & 36 & 3,862 \\
Lusaka Township & 1,280 & 7,485 & 59 & 7,544 \\
Livingstone Municipality & 4,786 & 6,306 & 63 & 6,369 \\
Nchanga Mine Township & 2,988 & 4,181 & 34 & 4,215 \\
Kitwe Township & {$[\mathrm{na}]$} & 2,544 & 37 & 2,581 \\
Nkana Mine Township & 7,889 & 11,235 & 63 & 11,298 \\
Luanshya Township & & 1,887 & 24 & 1,911 \\
Roan Antelope Mine Township & 7,796 & 10,540 & 86 & 10,626 \\
$\quad$ Roan Antelope North (Suburb) & & 321 & 9 & 330 \\
Mufulira Township & 3,548 & 1,707 & 37 & 1,744 \\
Mufulira Mine Township & & 8,013 & 73 & 8,086 \\
Ndola Municipality & 4,481 & $\mathbf{5 , 9 3 3}$ & 85 & 6,018 \\
$\quad$ Manners Township (Suburb) & & 662 & 9 & 671 \\
\hline
\end{tabular}

Source: Report on the Census of the Population of Northern Rhodesia Held on 15th October, 1946 (Lusaka: Government Printer, 1949), Table 2, p. 69.

meant a new division of powers among the colonial, federal, and territorial governments. This, coupled with an economic decline in the last half of the 1950 s, meant that revenues for housing were scarce. In fact, there was a housing shortage for all races.

In the late 1940s' atmosphere of rapid economic growth and severe labor shortages, colonial authorities singled out domestic service as a sector in which too much African male labor was "wasted." African men could be put to more profitable use elsewhere, their argument ran, so why not employ African women as servants? They were considered lazy and idle anyway, so service would be good for them. The ambiguous and at times contradictory attitudes of whites and Africans, males and females, to the woman question in domestic service were laid open in the debate that followed. This debate provides a unique historical moment that gives dramatic evidence about the workings of colonial gender ideology and of the social impacts of its sexual assumptions.

The question of employing African women in service-oriented work had been raised before the 1940s. The legislative council had already in 1929 suggested the employment of African women servants in girls' schools and as ward-maids in European hospitals. The proposal floundered because of the lack of separate living quarters for such African women in the hospital in Livingstone and the boarding school in Choma. ${ }^{128}$

128. NAZ/ZA 1/9 no. 49. Department of Native Affairs. Licensing and Registration of Domestic Servants. Secretary for Native Affairs to Chief Secretary. September 4, 1929. 
Later, at the height of the repatriation attempts, native authorities were asked their opinion about the entry of young African women into service. Most of them were against it. This rejection was expressed, among others, by native authorities from the copperbelt region, from Mpika, and by Lungu and Mambwe native authorities at meetings in 1938 concerning the education of boys and girls. Yet representatives of the Abercorn Local Native Welfare Association, which had a more modern outlook than the chiefs, considered such employment suitable for unmarried women after, but not before, they had received some education. ${ }^{129}$

When during World War II the call for African women workers was made more urgently, it was first seen as a partial solution to wartime labor shortages in the farm sector. A circular from the chief secretary's office to all labor officers, provincial commissioners, and district commissioners encouraged them to undertake "the most effective propaganda . . to overcome prejudices . . . to persuade women to do more [agricultural work] in order that a higher proportion of men may be released for essential war work." 130 The call was extended to domestic service at the beginning of the war: "we could raise another battalion of men who could do better than sweep floors." 131 The chief secretary and the labor commissioner doubted from the outset that they would succeed, for, "as you are aware", the latter reminded the former, "the difficulties are great in this territory." $132 \mathrm{Al}$ though the chief secretary did draft a propaganda article for inclusion in the vernacular newspaper, Mutende, encouraging African women to seek work as servants, no concerted campaign was set into motion at this time. ${ }^{133}$ As in 1929, the lack of suitable accommodation was viewed as the main obstacle. The colonial administration did not act on a resolution on social welfare, adopted by the 1943 synod of the Methodist Church in Northern Rhodesia, which recommended that the government establish hostels either independently or through the management boards in towns, where employed African women could be trained under "suitable European control."134

129. NAZ/SEC 1/1316. Labour: Employment of Children 1938-1945. Native Education on the Mines. Notes of meeting with Senior Provincial Commissioner, Provincial Commissioner, and Director of Native Education, May 14, 1938. Dispatches on Education from District Commissioner, Abercorn, to Provincial Commissioner, Kasama. August 27, 1938; and from District Commissioner, Mpika, to Provincial Commissioner, Kasama. December 14, 1938.

130. NAZ/NR 3/143 md/14. Labour Department. Lative Labour Conditions. Labour Supplies. Womanpower. Circular no. 8 of 1943: African Womanpower, to All Labour Officers, Provincial Commissioners, and District Commissioners. March 17, 1943.

131. Comments by Harry Franklin, Director of Information. Northern Rhodesia. Legislative Council Debates 82 (1954), July 26-29, col. 284.

132. NAZ/NR 3/143. Labour Commissioner to Chief Secretary. June 1943.

133. NAZ/NR 3/143. Chief Secretary to Labour Commissioner. June 1, 1943.

134. NAZ/SEC 1/1350. Repatriation, Methodist Church Synod. November 1943. 
The call to hire African women workers was voiced again in the late 1940s, when the economy had picked up and white immigration was growing, especially in the mining towns and the tobacco-growing areas. There were labor shortages in all sectors of the economy, particularly farming. White farmers clamored for government support to ease their labor shortage. ${ }^{135}$ The demand for servants also increased, for most whites, including the new arrivals, commonly employed several. Many of the new immigrants came from South Africa, where at this time African women had almost displaced African men in domestic service. Yet in Northern Rhodesia the immigrating whites adjusted with alacrity to the prevailing practice of employing African menservants, assimilating local conventions in household employment. They, and other private householders, complained about the supply of good servants, meaning men.

When white male officials staged the postwar African womanpower campaign it was, as in the previous instances, first aimed at lessening the farm labor shortage by encouraging African women to work as farmhands. White farmers along the line-of-rail, the area where the majority of the commercial farms were located, suggested that native authorities be charged with making propaganda to encourage African women and young persons to turn out for farm work. ${ }^{136}$ Several farmers had experimented with the employment of women and some had even fetched women from the nearby reserves. Others managed to talk the wives of male farmhands into helping with hoeing and harvesting. But many wives "refuse[d] blankly to do any work whatsoever." 137 In the farmer's view, the administration was biased toward the mines and the towns and did not do enough for them. The labor reports from the late 1940s and early 1950s show that farmers frequently criticized the authorities for inactivity on "the loafer issue." Loafers in towns, assumed to be hangers-on, persons without work and shelter living by their wit, could presumably be engaged in agricultural work. On that score farmers had little success, and, in fact, it is doubtful that the towns were full of loafers during the labor shortages of the early fifties. When township authorities made an effort to relieve the farmers' troubles by arranging for a supply of women and youth from the city compounds, the farmers chose not to accept them. ${ }^{138}$ In the farmers' view, there were too

135. In an effort to support white farmers, the government established the African Labour Corps, which between 1942 and 1952 made conscripted African male workers available for farm work at wages that were subsidized by the government. See Kusum Datta, "Farm Labour, Agrarian Capital, and the State in Colonial Zambia: The African Labour Corps, 19421952," Journal of Southern African Studies, 14 (1988): 370-392.

136. NAZ/NR 3/143. Chief Labour Officer to Secretary for Native Affairs, Lusaka. September $28,1950$.

137. NAZ/NR 3/199. Annual Reports. Senior Labour Officer, Lusaka, 1950-1960. Philpot reporting from the Southern Area, 1950.

138. Ibid. 


\section{A Fixture of Colonial Society}

many problems involved in employing African women. Only in tobacco grading was some success achieved, which was attributed to women's manual dexterity and "natural suitability" for the task. A touring labor officer summarized the farmers' attitudes to African women's work as: women can't work; they are too lazy; or women won't work even if offered high wages and full rations because their husbands won't allow them. ${ }^{139}$

These complaints were elaborated by a labor officer after an inspection tour of white farms in the territory's southern part. His remarks highlight the authorities' limited understanding of African women's work and reveal the emphasis on education as a solution to "the woman problem." His assumptions were shared by much of white colonial society and were central in the subsequent debate.

It is generally felt by farmers that as the only work [an African woman] has to do is to cook her husband's food she might show some gratitude for services rendered by helping to keep the compound clean and doing some occasional work on the farm. . . . There is no regular attendance [in farm work] and there is little doubt that on the whole the African woman is very much more trouble than she is worth on a farm, but she is unfortunately a necessary evil, she is the cause of a large amount of the discontent among the labour, she is filthy in her person and in her habits and is more often than not riddled with disease, she is pig headed and uneducated and till such time as she is brought into line, educated, and taught at least, some of the decencies of life, she will not be able to become a helpful member of the community. ${ }^{140}$

Farmers would have been unlikely to receive much support from the administration, who understood that rural African women's productive work in cultivation was crucial in efforts to maintain subsistence. From the viewpoint of colonial administrators, it was not at all advisable to recruit women from the reserves: "the main point is that we don't want to take women away from villages growing food. . . . We are encouraging the African to grow more food and women and children are concerned in this. .. . There is a need to harness womanpower where not otherwise usefully employed. There are more males in domestic service than any other industry save mining. I wish we could get women in the town compounds to work (italics added). ${ }^{141}$

The continuing debate revolved around the question of how to get urban African women into domestic service. Reducing the number of men employed as servants would be part of a solution to the shortage of labor on

139. Ibid. Tour Reports of Farms West of Lusaka. July 1951.

140. Ibid. Tour Reports of Farms in the Mazabuka, Monze, and Pemba Areas. 1948.

141. NAZ/NR 3/198. Tour Reports of Labour Officers, Lusaka, 1950-1955. May 1951; and NAZ/SEC 5/331. Native Labour. General Policy 1949-1951. Comments on dispatches by Commissioner of Labour and Mines. September 28, 1950. 
farms, according to the Northern Rhodesia Farmers' Unions, ${ }^{142}$ and in towns, in the view of male colonial administrators and such philanthropic groups as churches and welfare organizations. The issues of primary concern in the discussion of how to bring about a gender transformation in domestic service had been anticipated in the previous debate. One was the question of how to house women servants, another, the matter of training, and a third was the question of whether women servants should be single or married.

The suggestions offered on these issues in Northern Rhodesia are likely to have been influenced by the experience with African women domestics in the south. In Southern Rhodesia in the early 1930s, the legislative assembly had established a committee to prepare a report on the subject. It took extensive evidence from employers in the main towns, from location officials and educational staff, church representatives, African welfare associations, and white women's voluntary organizations. The committee also gathered information about women's hostels in South Africa, where they had operated since before the turn of the century, ${ }^{143}$ and about the Native Girls' Hostel in Umtali in Southern Rhodesia, run in 1933 by the Women's Foreign Missionary Society and the American Methodist Episcopal Church. Commenting on the report in 1932, the chief native commissioner of Southern Rhodesia recommended that the government should not, at that time, take any specific steps to encourage African women to come to towns to work. But since that movement had already begun, steps should be taken to direct it into "safe channels" by providing hostels and domestic training, especially for detribalized urban women. ${ }^{144}$

Providing hostels seemed to be an idea then in vogue, its precedent dating back to Britain in the 1860 s and 1870 s, when large numbers of leisured Victorian women had entered the workhouses to train poor girls for domestic service. ${ }^{145}$ The Federation of African Welfare Societies in Southern Rhodesia involved themselves in the training of women domestics in Umtali in the early 1950s. Some thirty young women were accommodated at the center for three to four months and taught "household English," the use of kitchen utensils, washing, cleaning, mending, waiting on table, and simple cooking. ${ }^{146}$

142. Comments made by B. Goodwin of the Northern Rhodesia Farmers' Union at a conference called by the government on African labor problems. "Too Many Natives in Domestic Service Say Farmers," Central African Post, October 19, 1950, p. 12.

143. Gaitskell, "Christian Compounds."

144. NAZIM/S 1561/48. Female Domestic Service. Labour Memoranda and Minutes, 1931-1947. Comments by H. U. Moffat.

145. F. K. Prochaska, "Female Philantropy and Domestic Service in Victorian England," Bulletin of the Institute of Historical Research, 54 (1981): 79-85.

146. NAZ/NR 2/27. African Welfare. General Correspondence. African Welfare Bulletin, by the Federation of African Welfare Societies in Southern Rhodesia, Bulawayo, no. 97. May 1953. 


\section{A Fixture of Colonial Society}

The Northern Rhodesian government, however, did not approach the question as systematically as their southern neighbors had. No general investigation was undertaken, although labor officials met and various private bodies, representing white employers and philanthropic groups, made their opinion known. While there was general agreement that African women had to be trained for domestic service, diverse suggestions were made for their housing. The chairman of a location superintendents' conference at Ndola in 1947 anticipated that white employers would be so glad to get properly trained African women servants that they would be willing to extend their homes to house them. Such accommodation would be, he suggested, "in [the employers'] own interests, for these girls would at the same time be protected from unwise attention of the local bloods and would be available on the premises to look after European children left in the evening by their parents." 147

This official had reacted negatively to the suggestion of building women's hostels in the middle of the white residential areas or in the African townships. But most of the other suggestions involved such hostels. The idea was elaborated by the Anglican bishop of Northern Rhodesia, Robert Selby Taylor, who in 1949 invited government officials to a meeting at which he intended to set up a committee to work out a proposal for the establishment of a domestic training center in Lusaka. It was to accommodate about thirty African women and to be supervised by white women who would instruct them in "housewifery under European conditions." As he envisioned it, the costs were to be shared between the church and the government. ${ }^{148}$ Dealing somewhat summarily with the bishop's idea and sending a subordinate official to the meeting, the secretary for native affairs rejected the notion of strong government involvement: "let him do the training with whatever financial assistance he can get out of Government" and place the responsibility for housing women when employed with the local authorities. ${ }^{149}$ On the other hand, the Federation of Women's Institutes in Northern Rhodesia passed a resolution calling for the government to "include within its new African Housing Scheme the building of hostels for African women in employment . . . [to] be supervised by [white] African welfare officers."150

Hostels for African women might have seemed an attractive idea for several reasons. By restricting the movements of African women in towns, authorities could reduce the chances of sexual involvements when women were away from work. This advantage was likely to appeal to rural native

147. Comments on conference of location superintendents at Ndola concerning African labor. Livingstone Mail, May 2, 1947, p. 3.

148. Northern Rhodesia. Legislative Council Debates 82 (1954), July 26-29, col. 268, and 65 (1949), September 7-16, col. 231.

149. NAZ/NR 3/143. Comments on the Bishop's scheme. August 29, 1950.

150. Ibid. The file includes the resolution quoted in the text. 


\section{Women for Hire? Sex and Gender in Domestic Service}

authorities, who continued to object to the allegedly freewheeling town lifestyle of the African women under their jurisdiction. Furthermore, supervision and domestic-service training by white women might serve as a form of ideological control by instilling in African women white middleclass values of home and housekeeping. In this way, presumably, they might eventually become incorporated into the colonial order as houseproud wives rather than partners in sexual play. ${ }^{151}$ The managers of industry, however, anxious to recruit male labor, had little to gain by segregating women domestics into residential areas separate from men and away from the white suburbs. And the government itself was not forthcoming with funds to support the building of hostels. When the bishop died in 1951, so did the training and hostel scheme, "largely due to lack of funds and other difficulties. ${ }^{152}$ Churches and missions in Northern Rhodesia never involved themselves in housing and training African women domestics to the same extent that they did in the south. They may have seen their primary purpose as training African women not for domestic service, but for selfimprovement and home management so as to make them into better mothers. With this task, in fact, they had their hands full already. ${ }^{153}$

While labor officials at several meetings agreed that African men ought to be released from domestic service to work in other areas, their opinions varied as to which women should work as servants and how they should be trained. The participants at a 1950 labor conference recommended training courses of short duration. They regarded African women as "absolutely raw material, . . . if it lasted longer . . . it [is] probable that women would not stick it. . . An African woman does not normally remain unmarried after the age of 17 and it is possible that floating unmarried women in the big towns would not be very desirable characters to bring into European homes." As an alternative, one official suggested that the wives of men domestics be trained. Such a course might lessen the housing problem; on

151. The education of African women was informed by the explicit ideology of making them houseproud. For an early formulation of housepride which influenced colonial policy of African women's education, see PRO/CO 795/158 no. 45469. Miss Gwilliam and Margaret Read, Report on the Education of Women and Girls in Northern Rhodesia, 1949.

152. Northern Rhodesia. Legislative Council Debates 86 (1955), November 29-December 16 , col. 144.

153. The United Missions to the Copperbelt had begun educational efforts directed toward girls in the mid-1930s, described in Taylor and Lehmann, Christians of the Copperbelt. For the ideology that guided women's education, see also Hay Hope, "An African Women's Institute," Overseas Education 10 (93): 104-107, and Sean Morrow, "Some Social Consequences of Mission Education: The Case of Mbereshi, 1915-1940," History in Zambia 11 (1981): 10-23. Mabel Shaw, headmistress of the London Missionary Society's girls's school at Mbereshi saw the role of education above all as the molding of Christian mothers and wives. She did not agree with the policies of the administration: "It is high time they were reminded that our ideals are not theirs, and that the only kind of education we are interested in is religious" (Morrow, p. 14). 
the other hand, they "might have to consider creches where children of female domestics could be left during normal working hours." The secretary for native affairs questioned the suggestion, arguing that "African women (and European women for that matter) who have children at home should stay at home to look after them. In any event native opinion would take years to come round to the idea that women with families should work for wages." 154

As the 1940s turned into the 1950s, very few African women indeed were employed as domestic servants. The years 1951 to 1957 and 1961 to 1968 are the only time spans for which I have located employment figures categorized by sex (see Table 5 and Table 6 ). Although the official figures are likely to underestimate the actual extent of service employment, the gender gap is notable. Among the very few women who did work as servants during those years, some are likely to have been introduced to the occupation through a couple of specially organized efforts.

A kind of labor exchange, called the Women's Labour Bureau, was set up in Lusaka in 1950 in a cooperative effort between the Labour Officer and the white female welfare officer in the African Welfare Department of the town's management board. ${ }^{155}$ During her daily house visits in the compounds, the welfare officer notified the young girls with Standard IV education who sat at home "doing nothing" of the possibility of working in domestic service. They could "not only train as nurse girls given suitable conditions but some of them could in time become efficient domestic servants." It would be a difficult task, though, for it was "obvious that a great deal of time must be devoted to these girls if they are to learn anything at all." 156 In a 1950 letter to the editor of the Central African Post, which ran under the heading "Training for African Women," four white women who described themselves as "enthusiastic supporters of any scheme for training Native girls for domestic service," expressed the same attitude. In their view, such training should be undertaken by "honest-to-goodness women with a sound knowledge of Rhodesian homes and how they are run [because] only women who have lived among Africans have a glimmering idea of the primitive condition of the African female." 157

154. NAZ/NR 3/143. Commissioner of Labour and Mines. September 28, 1950; and Chief Secretary. September 29, 1950.

155. Welfare departments had been established in all the towns by 1950 . The passing of the Colonial Development and Welfare Act of 1940 made financial assistance available for many activities in the realm of social welfare, and a social welfare advisor was added to the Colonial Office staff in London in 1947. When local welfare departments were established in the postwar years, they sought in particular to deal with youth and to counteract the effects of detribalization and drift away from villages. Sir Charles Jeffries, The Colonial Office (London: Allen and Unwin, 1956), pp. 151-153, 160-166.

156. NAZ/NR 2/27. African Welfare. General Correspondence, 1944-1954. News Sheet of the African Welfare Department, no. 10. November 1950.

157. "Training for African Women," Letter to the Editor, Central African Post, December 14,1950 , p. 3 . 
The failure of the Lusaka Women's Labour Bureau was anticipated a year later in the welfare department's newsletter: "It would assist the successful running of the bureau if interested Europeans would get in touch with the welfare section giving information as to the type of girl they wish to employ, what accommodation is available and in what type of work." 158 The bureau, according to an official, had placed only two or three women. "The ones I have seen," he commented, "could hardly be described as 'good' girls in every case, and I myself have not taken one so far. Other employers have done so but the girl has got tired within a week and left saying either: a) that the Dona made too much noise, or b) that the journey to the place of work was too great, or c) that the houseboys already on the job drove her away." He doubted that girls would "go in for" domestic service, even if they were trained: "I . . . think that our experience will follow Salisbury's and Southern Rhodesia's generally. There women are going into secondary industry in some numbers, having skipped the stage when they still work in private homes. . . . we shall not be as lucky as our grandparents who lived through the butler/footman era to that of the female servant before they reached the present one of 'do it yourself." "159

When, in 1943 the chief secretary's office suggested the idea of a propaganda campaign, as mentioned earlier, the director of information argued that the time was not ripe for a full-blown effort. He contended that African opinion had proved adamantly negative. And few white employers would be willing to hire women and train them. He nevertheless agreed to help prepare the ground. Among the remaining documentation are copies of letters he wrote to the editor of Mutende, to the broadcasting officer, and to the producer of the Central African Film Unit, suggesting "indirect propaganda" to persuade African women, especially in towns, to work for wages. In his letter to the producer of the film unit, he proposed a film that "in a simple and humdrum way" would persuade African women to work, particularly as servants: "a film with a story that would paint this moral . . that an African woman is happier or better off if she is working than if she is idle." 160

Propaganda of sorts was transmitted across the territory when the Central African Broadcasting Corporation chose the issue of African women for domestic service for its first program in a new series of roundtable discussions called African Forum in October 1952. The topic, "Should African Women Take On Paid Jobs in European Households?," had been announced in advance and an indirect campaign set into motion in a series of talks concerning African women's education. A background write-up in

158. NAZ/NR 2/27. News Sheet, no. 21. September 1951.

159. NAZ/NR 3/143. P. J. Law for Commissioner of Labour and Mines to Secretary for Native Afffirs. November 23, 1951.

160. NAZ/SEC 5/331. Native Labour. General Policy, 1949-1951. Copies of letters included. 


\section{A Fixture of Colonial Society}

Table 5. Estimated number of Africans employed in industry and services in Zambia, by occupational field and by sex, 1951-1957

\begin{tabular}{|c|c|c|c|c|c|c|}
\hline \multirow[b]{2}{*}{ Occupational field } & \multicolumn{2}{|c|}{1951} & \multicolumn{2}{|c|}{1952} & \multicolumn{2}{|c|}{1953} \\
\hline & Males & Females & Males & Females & Males & Females \\
\hline Agriculture & 34,000 & 3,882 & 39,500 & 1,290 & 40,000 & 4,150 \\
\hline Butcheries & 250 & & 600 & & 900 & \\
\hline Bakeries & 650 & & 600 & & 700 & \\
\hline Brickfields & 5,000 & & 3,000 & & 4,000 & \\
\hline Building & 17,000 & & 17,000 & & 21,000 & \\
\hline \multicolumn{7}{|l|}{ Civil engineering } \\
\hline Cordwood cutting & 7,000 & 105 & 12,000 & & 8,500 & 70 \\
\hline Factories & 10,200 & 50 & 4,500 & 50 & 3,900 & \\
\hline Domestic service & 30,000 & 250 & 31,000 & 600 & 35,000 & 700 \\
\hline Flour mills & 750 & & 800 & & 800 & \\
\hline Garages & 2,000 & & 2,000 & & 2,250 & \\
\hline Government (exc. roads) & 7,700 & & 11,080 & & 32,000 & \\
\hline Hotel and catering & 1,000 & & 2,148 & 5 & 2,200 & 10 \\
\hline $\begin{array}{l}\text { Municipalities and local au- } \\
\text { thorities }\end{array}$ & 4,500 & 62 & 4,300 & 40 & 5,400 & 50 \\
\hline Mines (all) & 42,000 & 150 & 42,000 & 190 & 46,000 & 100 \\
\hline Quarries and lime works & 2,400 & & 3,000 & & 3,300 & \\
\hline Roadwork & 5,000 & & 5,000 & & 4,500 & \\
\hline Railways & 4,400 & 5 & 4,600 & & 4,650 & \\
\hline Saw mills & 4,000 & & 3,200 & & 3,500 & \\
\hline Transport companies & 3,000 & & 3,000 & & 3,500 & \\
\hline \multicolumn{7}{|l|}{ Wholesale and retail } \\
\hline distributive trade & 10,000 & 10 & 65,000 & 5 & 6,800 & 10 \\
\hline $\begin{array}{l}\text { Native authorities, African } \\
\text { employed, self-employed, } \\
\text { etc. }\end{array}$ & 11,000 & 200 & 24,000 & & 35,000 & 10 \\
\hline \multicolumn{7}{|l|}{$\begin{array}{l}\text { Unified African teaching } \\
\text { service }\end{array}$} \\
\hline \multicolumn{7}{|l|}{ Miscellaneous } \\
\hline Total & 201,850 & 4,714 & 229,828 & 2,180 & 263,900 & 5,100 \\
\hline $\begin{array}{l}\text { aincludes } 500 \text { part-time teac } \\
\text { bincludes } 500 \text { part-time teac } \\
\text { cincludes } 500 \text { part-time teac } \\
\text { dincludes } 500 \text { part-time teac }\end{array}$ & & & & & & \\
\hline
\end{tabular}

the monthly radio magazine, the African Listener, sought to campaign. It highlighted the importance of education for urban African women's household management and their need to learn new ways of cooking to enable them to cater to their husbands' wishes, especially those who worked in white households: "It would also be a very good thing if African women were educated enough to do much of the work in the towns which is now done by men. Does it not seem strange that African men should be seen looking after European children in the towns, scrubbing floors in the houses, cooking food and washing clothes? Europeans think this is women's 
Women for Hire? Sex and Gender in Domestic Service

\begin{tabular}{|c|c|c|c|c|c|c|c|}
\hline \multicolumn{2}{|c|}{1954} & \multicolumn{2}{|c|}{1955} & \multicolumn{2}{|c|}{1956} & \multicolumn{2}{|c|}{1957} \\
\hline Males & Females & Males & Females & Males & Females & Males & Females \\
\hline 36,000 & 4,250 & 31,700 & 4,000 & 28,215 & 3,400 & 28,820 & 6,520 \\
\hline 1,000 & & 1,085 & 5 & 1,295 & & 1,330 & \\
\hline 800 & & 750 & & 850 & & 720 & \\
\hline 5,000 & 5 & 5,170 & 5 & 5,050 & & 4,350 & 5 \\
\hline 22,500 & & 29,700 & & 26,610 & & 22,600 & \\
\hline 3,500 & & 1,930 & & 2,500 & & & \\
\hline 8,000 & 120 & 3,100 & 50 & 1,515 & & 1,170 & \\
\hline 5,250 & & 5,700 & 50 & 5,900 & 65 & 6,800 & 30 \\
\hline 30,000 & 800 & 32,800 & 850 & 33,600 & 855 & 33,000 & 800 \\
\hline 800 & & 900 & & 950 & & 1,085 & \\
\hline 2,500 & & 2,500 & & 2,500 & & 1,950 & \\
\hline 31,725 & & 33,700 & 250 & 38,850 & 260 & 34,100 & 300 \\
\hline 2,500 & 10 & 2,560 & 10 & 2,500 & 10 & 2,310 & 30 \\
\hline 5,500 & 60 & 6,650 & 5 & 7,035 & 5 & 6,975 & 85 \\
\hline 45,000 & 100 & 44,700 & 100 & 45,540 & 450 & 44,250 & 500 \\
\hline 3,000 & & 2,750 & & 2,250 & & 2,330 & \\
\hline 1,200 & & 2,250 & & 2,895 & & 3,050 & \\
\hline 4,815 & & 5,250 & 5 & 6,410 & 5 & 6,300 & 5 \\
\hline 3,500 & & 2,530 & 25 & 950 & & 2,480 & \\
\hline 3,750 & & 3,850 & & 4,675 & & 4,775 & \\
\hline 7,500 & 15 & 7,950 & 15 & 8,800 & & 9,400 & 75 \\
\hline 30,000 & 15 & 21,000 & 15 & 21,000 & 50 & 20,000 & 50 \\
\hline 3,500 & $1,000^{a}$ & 3,850 & $1,050^{\mathrm{b}}$ & 4,125 & $1,455^{c}$ & 4,500 & $1,350^{\mathrm{d}}$ \\
\hline 1,000 & & 3,000 & 30 & 3,600 & 40 & 5,000 & 40 \\
\hline 258,340 & 6685 & 255,375 & 6,510 & 257,615 & 6,670 & 247,475 & 9,790 \\
\hline
\end{tabular}

work; Africans, in their own villages, think so too. If the women did this work it would release many men to do other work which women cannot do-mining, making railways, driving lorries, building houses and offices and so on."161

The participants in the African Forum roundtable included the labor commissioner and three African men: a clerk in the colonial secretariat and two inspectors of cooperative societies. No African women were invited. These three African men of elite status did not emulate white attitudes.

161. African Listener 1 (1952), January, p. 17. 


\section{A Fixture of Colonial Society}

Table 6. Estimated number of Africans employed in industry and services* in Zambia, by occupational field and by sex, 1961-1968

\begin{tabular}{|c|c|c|c|c|c|c|}
\hline \multirow[b]{2}{*}{ Occupational field } & \multicolumn{2}{|c|}{1961} & \multicolumn{2}{|c|}{1962} & \multicolumn{2}{|c|}{1963} \\
\hline & Males & Females & Males & Females & Males & Females \\
\hline $\begin{array}{l}\text { Agriculture, forestry, and } \\
\text { fisheries }\end{array}$ & 21,852 & 579 & 24,384 & 649 & 23,899 & 753 \\
\hline Mining and quarrying & 2,635 & 4 & $39,636 \dagger$ & 482 & 2,034 & \\
\hline \multicolumn{7}{|l|}{ Manufacturing } \\
\hline Food processing & 3,753 & 28 & 4,016 & 7 & 6,144 & 102 \\
\hline Clothing and apparel & 787 & 30 & 902 & 27 & 882 & 8 \\
\hline $\begin{array}{l}\text { Furniture, leather, paper } \\
\text { and chemicals }\end{array}$ & 1,415 & 1 & 1,400 & 2 & 1,457 & 1 \\
\hline Bricks and cement & 2,576 & & 2,489 & & 2,337 & 1 \\
\hline Metals and machinery & 3,945 & & 3,990 & & 3,968 & I \\
\hline Building and construction & 15,457 & & 13,175 & & 12,717 & 1 \\
\hline $\begin{array}{l}\text { Electricity, water and sani- } \\
\text { tation }\end{array}$ & 1,933 & 5 & 1,087 & & 1,069 & \\
\hline Wholesale and retail trade & 7,681 & 52 & 7,502 & 68 & 8,027 & 86 \\
\hline Finance and real estate & 401 & & 369 & 1 & 378 & 1 \\
\hline Transportation & 3,236 & 1 & 3,593 & & 3,594 & \\
\hline $\begin{array}{l}\text { Local government, educa- } \\
\text { tion, health, community } \\
\text { service }\end{array}$ & 6,611 & 256 & 8,517 & 353 & 8,386 & 356 \\
\hline $\begin{array}{l}\text { Recreation and entertain- } \\
\text { ment }\end{array}$ & 1,155 & 10 & 1,078 & 56 & 996 & 50 \\
\hline Domestic service & & & & & 27,240 & 708 \\
\hline Restaurants and hotels & 2,683 & 82 & 2,632 & 127 & 2,503 & 177 \\
\hline Personal services & 402 & 5 & 382 & 12 & 498 & 4 \\
\hline Total & 76,522 & 1,053 & $\overline{115,152}$ & 1,784 & $\overline{106,129}$ & 2,249 \\
\hline
\end{tabular}

*This table covers a less extensive regional scope than Table 5. Thus the 1961-1962 figures are confined to the line of rail in the Southern, Central and Western provinces; the 1963-1964 figures exclude NorthWestern Province and the Barotseland Protectorate; the 1965-1966 figures exclude North-Western Province and Barotseland Province; and the 1967-1968 figures exclude North-Western Province.

†The enumeration of males and females under the mining and quarrying category in 1962 is conspicuously larger than in previous and later years. I suggest that some employees in larger mines are included in the 1962 figures.

Source. Annual Reports of the Department of Labour, 1961-1963 and 1964-1968, Table I(b). Some eighty occupational groups have been merged for use in this table.

They argued that educated African wives had enough to do in their own homes. A Eurafrican woman (that is, a person of mixed racial background), Agnes Morton, who was a well-known and very popular radio producer of women's programs, took issue with them in the African Listener. She suggested work as part-time servants, especially by newly married wives without children. Such employment would help financially and they would learn a great deal from white women. "I am very surprised," she wrote, "that these ... well-educated gentlemen should cut down the oppor- 


\begin{tabular}{|c|c|c|c|c|c|c|c|c|c|}
\hline \multicolumn{2}{|c|}{1964} & \multicolumn{2}{|c|}{1965} & \multicolumn{2}{|c|}{1966} & \multicolumn{2}{|c|}{1967} & \multicolumn{2}{|c|}{1968} \\
\hline Males & Females & Males & Females & Males & Females & Males & Females & Males & Females \\
\hline 23,307 & 709 & 26,071 & 827 & 26,561 & 817 & 27,100 & 608 & 22,782 & 332 \\
\hline 2,650 & & 2,639 & 7 & 2,162 & 7 & 3,585 & 2 & 3,076 & 2 \\
\hline 6,139 & 171 & 6,860 & 122 & 5,683 & 169 & 7,085 & 191 & 7,291 & 188 \\
\hline 1,224 & 42 & 2,428 & 177 & 2,961 & 115 & 4,415 & 201 & 3,715 & 170 \\
\hline 1,814 & 9 & 2,664 & 17 & 2,477 & 22 & 3,844 & 18 & 3,637 & 33 \\
\hline 2,238 & 4 & 3,383 & 7 & 1,607 & 1 & 2,705 & & 2,705 & 11 \\
\hline 5,167 & 5 & 4,934 & 4 & 4,683 & 5 & 6,264 & 12 & 7,854 & 11 \\
\hline 15,189 & 106 & 22,460 & 597 & 21,617 & 5 & 22,558 & 9 & 26,132 & 21 \\
\hline 1,154 & & 1,349 & & 1,072 & & 1,223 & & 795 & \\
\hline 8,753 & 275 & 8,573 & 266 & 8,875 & 344 & 8,466 & 299 & 10,922 & 490 \\
\hline 483 & 2 & 777 & 7 & 754 & 9 & 955 & 15 & 1,042 & 36 \\
\hline 3,304 & & 3,342 & 7 & 3,346 & 14 & 5,016 & 13 & 5,352 & 46 \\
\hline 11,603 & 457 & 12,342 & 604 & 9,347 & 480 & 13,698 & 435 & 7,515 & 389 \\
\hline 1,117 & 42 & 1,018 & 1 & 1,037 & 54 & 829 & 21 & 929 & 48 \\
\hline 26,800 & 700 & 31,500 & 800 & 31,231 & 1,498 & 31,508 & 1,549 & 36,491 & 1,758 \\
\hline 2,429 & 208 & 2,610 & 258 & 2,696 & 252 & 2,564 & 336 & 2,316 & 359 \\
\hline 473 & 9 & 605 & 7 & 552 & 9 & 523 & 25 & 867 & 17 \\
\hline 113,844 & 2,739 & $\overline{133,654}$ & 3,706 & 126,661 & 3,801 & 142,348 & 3,734 & 143,421 & 3,911 \\
\hline
\end{tabular}

tunities of African wives of helping financially. This kind of opposition is just to show Europeans that African husbands do not yet trust their wives." 162

The debate about hiring women for domestic service dragged on through the first half of the 1950s. In “Too Many Cooks," a letter to the editor of the Central African Post in 1954, the writer complained that "this country cannot go on forever employing able-bodied adult men in work which is traditionally women's work." In another letter, "Domestic Service Plea," it

162. African Listener 12 (1952), December, p. 16. Miss Morton, born between 1910 and 1920, was a daughter of a white district commissioner at Mansa and a granddaughter of the first Chief Kazembe. She had been schooled at the London Missionary Society's school at Mbereshi till standard 4, took standard 5 through 6 in Southern Rhodesia, and subsequently trained as a teacher at Hope Fountain Girls' Institute in Bulawayo, Southern Rhodesia. Before becoming a broadcaster in 1949, she taught domestic science in girls' schools in Northern Rhodesia. She never married. Zambia Daily Mail, July 23, 1981, p. 7. 
was argued that employment of African women in service would help in the "advancement of the African." 163 And a leading newspaper in 1955 ran an article in which the home environment was pointed to as the greatest handicap for Africans, particularly for women "still content to squat outside their front door and watch life pass them by." In order to advance, women, it was suggested, should replace men in domestic service. ${ }^{164}$

Toward that end a scheme had been launched at Ndola in 1954. Organized by the Federation of Women's Institutes in cooperation with the labor department, the African Charwoman Scheme made part-time domestics available to residents of flats and to white women in retirement homes. It was different from earlier efforts in that it involved not young girls but socalled "suitable" women, that is, women who had worked as servants in Southern Rhodesia or South Africa. The scheme was advertised in the Northern News, by the Ndola Chamber of Commerce, and by voluntary organizations. ${ }^{165}$ News about it was sent to labor officers in all the line-ofrail towns, who were encouraged to copy the plan. But by 1956 the Ndola scheme had failed and efforts to start similar schemes elsewhere had been unsuccessful. A labor officer explained: "While African women are not yet prepared to become proper full-time domestic servants, when they go to flats or part-time duties they tend to get involved with male servants and the usual difficult complications arise. No doubt under such circumstances husbands would not be prepared to let their wives go and work as charwomen if it might have a bad effect on marital relations. ${ }^{166}$

At that point, the labor commissioner was clearly fed up. All attempts had failed. His remarks added in longhand at the end of the official correspondence indicate his frustrations: "It is a pity but I do not think we can force the issue any more." 167 And it was not forced again. When in subsequent years the question occasionally arose in the legislative council, voluntary organizations were called on to train women for domestic service. ${ }^{168}$ None, to my knowledge, ever did.

The economy had entered a period of recession which lasted through the first years of independence. The tide had begun to turn in 1954, when for the first time in many years labor was plentiful. It continued to be in ample supply. There was unemployment among workers of all colors, and several

163. "Too Many Cooks," Letter to the Editor," Northern News, July 9, 1954.

164. Lead article, Central African Post, September 23, 1955, p. 4.

165. NAZ/NR 3/143. Labour Officer, Ndola, to Assistant Labour Commissioner, Kitwe.

166. Ibid. Acting Senior Labour Officer to Secretary, Northern Rhodesia Council of Social Services. January 7,1956 .

167. Ibid. Handwritten comments by Labour Commissioner. 1956.

168. Northern Rhodesia. Legislative Council Dehates 94 (1958), March 18-May 16, col. 145. 
white miners left the copperbelt and the country when copper prices dropped sharply in 1957. In 1958 even farmers had little difficulty obtaining labor. By 1960 there were thousands of unemployed African men in Lusaka and Livingstone. ${ }^{169}$ The argument that women should replace men in domestic service so as to release them for more productive work elsewhere was no longer heard.

\section{Economic Logic and Ideological Contradictions}

African women did not skip the stage of working in private homes because wage labor opportunities opened up for them in secondary industry. As the womanpower debate shows, they hardly began entering that stage. And secondary industry never developed to any significant degree except in activities that supplied the mining companies. ${ }^{170}$ When the mid-1950s' recession hit, African men kept their stronghold on domestic service, and the occupation remained for the entire colonial period predominantly a male preserve. Although men's persistence in domestic service may be attributed to supply and demand, such labor market factors do not explain why women were not recruited into domestic service at the height of the labor shortage at the turn of the 1940s and through the mid-1950s, when both the African and the white urban populations were growing rapidly and labor was scarce across the economy.

Assuming that units of labor were mutually interchangeable, male colonial officals argued that African women should replace men in domestic service to release the latter for work elsewhere. But sex was not an irrelevant factor in the market, and one occupation, domestic service, was construed in gender terms as male. The debate that ensued in the campaign for African womanpower was shot through with contradictions that embody complex ideological assumptions about sex and the gender division of labor in the late colonial situation. The same assumptions were not shared among male colonial authorities, white women employers and their men, and African women and men.

The lackluster performance of all participants in the campaign to hire African women workers may reflect that most of them doubted it would work. The "other difficulties" alluded to during the debate concerned the sexual ramifications of the scheme. Their sex became African women's liability and not an asset that "naturally" predisposed them for domestic

169. NAZ/NR 3/199. Annual Reports. Labour Officer, Lusaka. 1960.

170. Robert E. Baldwin, Economic Development and Export Growth: A Study of Northern Rhodesia, 1920-1960 (Berkeley: University of California Press, 1966), pp. 37-40. 


\section{A Fixture of Colonial Society}

work. Sex, with that word's many connotations in the colonial mindimmorality, promiscuity, prostitution, in short, sexuality-remained a charged issue. Young African girls were considered dangerous in colonial households for they were assumed to be sexually precocious, and married African women were suspected of adulterous sexual assignations. Then there was the unspoken question of how an African woman servant and the white madam's husband would confront one another.

In the view of white women householders, African women were less controllable than men; they were less submissive and caused more problems in the running of the household. During the African womanpower campaign, white women held that African women were nowhere near capable of taking over from men in domestic service and made little or no effort to aid the situation. Their discourse comes close to depicting African women as a different species - certainly from themselves - and more primitive even than African men. The image was charged with sexuality, the African woman as "easy" temptress and-although it was not made explicit-a dangerous element in the white house.

The discussion about the need for training masked the sexuality issue. It was argued over and over again that African women needed education before they could go into service. White women were unwilling to socialize them into domestic labor on the job as they had done with previous generations of African men. In the past, men's work as servants had not been deemed problematic because they had little education. By contrast, and in the early days, many employers avoided mission boys who had a bit of education. Several had preferred "raw" natives whom they domesticated themselves. But when it came to considering the possible entry of African women into domestic service, their lack of education was held against them. When making this argument, white women presumably chose to disregard that the curriculum in girls' schools emphasized domestic science subjects with the aim of making African women good mothers and proud housewives. Yet these mutually contradictory attitudes about education did not cancel each other out. African women's presence in the white colonial household was too close for comfort.

Given the class structure and the color bar that delimited the vastly different livelihoods of Africans and whites in the colonial division of labor, African women's gains from education, homecraft centers and women's programs, and domestic work in white households were negligable. Housewifery and homepride were defined in terms of what was proper and useful in white households. But scotch eggs, muffins, and rice puddings, the recipes for which were offered to the new readers of the African Listener, were difficult to prepare in homes without wood stoves or electric cookers and seem jarringly out of tune with the culinary arts of the African lowincome household. Many of the skills African women might supposedly 
acquire from working in white households were similarly irrelevant. They certainly had been so for generations of menservants. Because of the substandard wages, African cooks and houseboys could make little practical use of their knowledge of roasts, mince pies, and custards. And the tableboy's manual dexterity in handling various types of flatware, cutlery, and glasses had little application in his own household. Moreover, in their own domestic settings, women were in charge of such matters. If African women were unenthusiastic about homecraft/housewifery classes, it may reflect the inapplicability to their everyday life of much of what patronizing whites taught them. Knitting, sewing, and embroidery seem to have been exceptions, perhaps because these skills could be used to turn out articles for personal wear or sale and thus supplement the household budget.

Colonial officials had described African men as "loath, not without reasons, to allow their wives to work away from home."171 The reason implied was their wives' likely sexual encounters with other men. Allowing "other men" to include whites, I suggest that several additional factors were influencing African men's attitudes toward women's work away from home. Their reluctance to send wives, sisters, and daughters into service in white households may reflect their unwillingness to expose them to a demeaning work relationship for which very low wages were paid. The matter of wages was never addressed in the debate. The few African women who did participate in the Ndola African Charwoman scheme in 1954 preferred to change from an hourly basis to "whole time employment as being more secure." 172 Their statement implied that part-time domestic service was hardly worthwhile economically.

But perhaps most important was the fact that paid household service conflicted with the demands placed on African women for their own domestic labor as broadly defined in cultural terms among the region's various ethnic groups. Across much of Africa, women and men regard the home as women's place and childcare and household tasks as their most important endeavors. Women's ability to prioritize this work was influenced by cultural practices that shaped gender relations within households and by the viability of their household economy. Speaking generally, such viability was affected by the region's productive potential, the economic needs and political capacity of the state to incorporate women as wage laborers, and by women's personal initiatives. Because of the sudden and haphazard nature of the recruitment campaign, African women in North-

171. NAZ/NR 3/199. Annual Reports. Senior Labour Officer, Lusaka, 1950-1960. Citation from 1955 report.

172. NAZ/NR 3/143. Labour Department. Native Labour. Conditions of Service. Labour Supplies. Womanpower, 1943-1956. Labour Officer, Ndola, to Acting Assistant Labour Commissioner, Kitwe. February 8, 1955. 


\section{A Fixture of Colonial Society}

ern Rhodesia were better able to resist the colonial government's attempt to incorporate them into domestic service than their sisters in South Africa. ${ }^{173}$

At the time of the womanpower campaign in Northern Rhodesia, the demands on African women's domestic labor from within their own households were much the same across class lines. This fact is borne out by the reactions of the male African participants in the African Forum radio debate, who objected to the idea of women going into service because they already had enough to attend to in their own homes. Colonial authorities failed to recognize the time-consuming nature of food processing and preparation and the constant demands that children and their care placed on women's attention and time. The demands of child care were particularly incompatible with paid domestic service, as most African women begin bearing children early and continue to give birth every two or three years throughout their childbearing years. Although authorities mentioned the need for creches, it was never attended to. African women of the early 1950s are likely to have shared the view on domestic service held by the women I spoke to between 1983 and 1985: a woman with small children simply does not leave her own household to attend to someone else's. And if she does, it is as a last resort, for who wants to be ordered around by another woman all the time on a slave wage? Whereas men, when all else has failed, and because they are normatively defined as heads of households, took and continue to take domestic service jobs because the economy has offered them few other wage labor opportunities.

Nowhere in the debate were African women called on to express their views. Their voice was silenced and they were assumed to want to work as servants. From the perspective of African women in the towns in the early 1950s, the division of labor which had existed in rural economies had been transformed. The contract migrant labor system that had forced men into wage labor on farms, in mines, and in private households over the preceding decades had gradually undermined rural women's autonomous roles in agricultural production. Their subsequent migration to towns, in spite of opposition by both colonial and rural native authorities, was in part their reaction to the deteriorating rural production opportunities. In this process of transformation, African women and men in towns were grappling with how to organize their urban households, relations among themselves, between themselves and their children and dependents, as well as with others in the towns, including white women and men. African women's un-

173. Belinda Bozolli, "Marxism, Feminism, and South African Studies," Journal of Southern African Studies 9 (1983), pp.149-155, reckons both with the capacity of indigeneous societies and of the state to subordinate women's labor when explaining the differential proletarianization of women in South Africa, as do Gaitskell et al., "Race, Class, and Gender," pp. 98-100. 
willingness to do wage labor as domestics may be seen as their attempt to resist any further loss of the limited independence they were establishing for themselves in their management of urban household activities.

By not "going in for" domestic service African urban women sought to define their own terms of work in ways that left them more freedom than they could hope for by working in low-paying jobs in white households. They are likely to have done so within a familiar frame. Rural women's desire for security within a household where they managed and worked in production, cared for children and grandchildren, contributed food and cooked for the household head ${ }^{174}$ did not change drastically in the urban setting. Urban African women wanted to be in charge themselves. Some traded from homes and yards, and the brewers and sellers of beer were sure to do a good business. Other women entered market trade. Because housing was tied to the job and few were employed, some women's terms of work included the exchange of sexual services and food preparation in cohabitational arrangements with men who provided them shelter.

The issue of prostitution and cohabitation with whites was not directly confronted in the African womanpower debate. The matter had been brought up in the legislative council in 1939, but nothing was done about it. 175 In 1942 one issue on the agenda at a public meeting in Mufulira was whether or not to introduce the South African Immorality Act, and a motion was carried unanimously to draw government attention to the matter. ${ }^{176}$ The question arose again in the legislative council in 1946. ${ }^{177}$ Among the waves of postwar white immigrants who worked in mines and construction were many single men who, like previous generations, sought sexual gratification from African women. At a conference in 1949 the district commissioner from Chingola complained that "few things . . . caused more anger amongst Africans than European men living with African women."178 A majority of those present voted that the government should introduce legislation to prohibit cohabitation between whites and Africans. Yet the matter was sensitive, for the authorities all knew of pioneers who had lived with African women in the bush for years, and they felt that it would be difficult to discriminate between old timers and others.

A variation on this theme was discussed in the legislative council as late as 1957 , when a motion was introduced to make miscegenation a criminal

174. Marcia Wright, Women in Peril: Lefe Stories of Four Captives (Lusaka: NECZAM, 1984), p. 59.

175. Northern Rhodesia. Legislative Council Debates 33 (1939), May 20-June 6, cols. 196197.

176. NAZ/SEC 1/1771. Public Opinion. Western Province, 1942-1945. Notes of a public meeting held at Mufulira on December 7, 1942.

177. Northern Rhodesia. Legislative Council Debates 54 (1946), May 6-June 7, cols. 17-18.

178. NAZ/SEC 5/114. Cohabitation, 1949-1957. Minutes of Conference of District Commissioners from the Western Province. 1949. 


\section{A Fixture of Colonial Society}

offense. A well-known racist, John Gaunt, who made the motion, was upset by seeing a good deal of miscegenation in Lusaka, which he attributed to the "getting into this territory certain people who do not have the same standards as the rest." His reference was to "foreign European labour . . . , birds of passage, . . . here to-day and gone to-morrow," who were unlikely to bring their children up "in the manner of the European." 179 His motion failed. Other members felt that miscegenation was inevitable in a multiracial society and that making it a criminal offense would not reduce it. ${ }^{180}$

Thus everybody knew of, and many objected to, sexual relationships between white men and African women, but legislators chose to do nothing about the situation. Delicate and embarrassing, the issue was rarely discussed in public, while at the same time everyone knew that it could happen and did. The private actions of African and white women were taken in the context of that knowledge. African and white women chose to not encounter one another in a servant/mistress relationship and thereby lessened the possibilities for compromising sexual involvements.

The sexuality argument conveys a rather denigrating view of white colonial women in Northern Rhodesia. To quality this view, we must reckon with their status as incorporated wives and with white colonial society's principles of male domination and female dependency. Other than their power to charm in the household context, as a newspaper commentator put it in 1909, white colonial women had little scope for autonomous activity and power acquisition in their own right in this class- and race-conscious society. The harbinger of unspeakable news in Page's novel explained to her friend that many white women overlooked their husbands' sexual habits; they had no choice, she said. A colonial white woman's main option was to see her husband as sexual protector, no matter what his extramarital involvements were.

But there were other choices. One was to leave. Barbara Carr recalled this when she "thought of the game rangers and planters and men of the administration, too, who had gone to England and brought back pretty young English brides who, when they discovered that their husbands owned large families of coloured piccanins had fled as fast as their . . . legs could carry them, back to their homes across the sea."181 Another was to engage in extramarital affairs with white men, although the extent of this practice may have been limited; the evidence does not give impression of bedhopping as practiced by white Kenya settlers in the Happy Valley. ${ }^{182}$

179. Northern Rhodesia. Legislative Council Debates 91 (1957) March 12-April 3, cols. $681,796$.

180. Ibid., cols. 683,793 .

181. Carr, Not for Me, pp. 174-175.

182. For the lifestyle of these white colonists in Kenya, see James Fox's carefuly researched real-life mystery, White Mischief (Harmondsworth: Penguin Books, 1982). 
Liaisons between white women and African men were another choice, but it was one considered even more despicable than relations between white men and African women. While they did occur, they were not widespread. Judging from contemporary writers such as Emily Bradley, white women are likely to have been very conscious of themselves as the embodiment of white womanhood and of the propriety expected of them in their roles as wives to powerful men. In the end, to play to the hilt the role of incorporated wife was these women's best choice.

The campaign for African womanpower had been the product of male officials who, vaguely doubting it would work anyway, could easily argue in the abstract the pros and cons of male versus female labor for domestic service, for they left to their wives the practical matters involving servants and their management. It is not surprising that colonial white women defended their place as mistresses of their own households when encouraged by male officials to hire African women. For white women, being aware of white men's sexual involvement with African women, may have seen any potential for such liaisons as jeopardizing their only position of strength. Given the structure of this situation, their decision not to employ African women servants in their homes may thus be interpreted as a singular feat by dependents of exercising personal power over their masters.

The dismal failure of the post-World War II campaign to recruit African women into domestic service was not due, as claimed, to lack of suitable housing, lack of education, or men's opposition. Although these factors influenced the outcome, they masked the key issue of sexuality. The debate about African womanpower may be viewed, I suggest, as a hegemonic moment in the Gramscian sense. Gramsci did not view ideology as unified or homogeneous, but always as made up of diverse and sometimes conflicting elements. ${ }^{183}$ Hegemony here means the way these elements are made to "hang together" in a relative, though never complete, unity. The debate about African womanpower at first seems to have been fraught with conflicting assumptions about sex and the division of labor by gender held by society's diverse segments. Male officials continued to view African women in terms of their sexual functions, and white women preferred not to have them in their homes. African men were reluctant to allow women to work away from home, and African women themselves were not overly keen on

183. The concept of egemonia recurs frequently in Gramsci's writings. Of the texts available in English, a selection on hegemony is included in Quintin Hoare and Geoffrey Smith, eds., Selections from the Prison Notebooks of Antonio Gramsci (New York: International Publishers, 1971). The first major clarification of the concept in English is Gwyn A. Williams, "The Concept of 'Egemonia' in the Thought of Antonio Gramsci: Some Notes on Interpretation," Journal of the History of Ideas 21 (1960): 586-599. See also Raymond Williams, "Base and Superstructure in Marxist Cultural Theory," in his Problems in Materialism and Culture: Selected Essays (London: Verso, 1980), pp. 31-49. 


\section{A Fixture of Colonial Society}

taking paid domestic work. Although their reasons differed, most people agreed: keep African women out of domestic service. As a hegemonic moment, the African womanpower campaign thus temporarily produced consent to the prevailing colonial social order in both its patriarchal and class dimensions.

\section{Non-African Women in Domestic Service}

When interviewing former employers of servants in Northern Rhodesia now living in England, I was told of individual cases of African women who worked in households as nannies. One was Julie Mulenga, also called Chikamoneka, a Bemba woman of royal descent born about 1900, who was known in Zambia as Mama UNIP (United National Independence Party) because of her role in anticolonial demonstrations before independence. One of her thirteen jobs over a span of twenty-five years was as nanny to the household of none other than "white-is-right" member of the legislative council, John Gaunt. ${ }^{184}$ Julia Mulenga and Betty Kaunda, the president's wife, ${ }^{185}$ were among the very few black African women to work in white households during the colonial period.

Although African men dominated in service, the occupation also saw a diverse contingent of non-African (meaning nonblack) women pass through it. Their presence lies hidden between the lines of obscure records that tell us little about them as persons or about their place in the evolving class system of the racially structured colonial situation. I discovered them when interviewing former employers and by examining job advertisements in the colonial newspapers. Such advertisements reveal a series of categories first of white, then of various shades of coloured, women passing through private household employment. Advertisements requesting African women for servants hardly ever appeared, and when they did, it was in the late 1950 s or early 1960s.

Northern Rhodesia's first newspaper, published in Livingstone from 1906, featured (by my reading) its first two situation-wanted ads in 1912, when a lady skilled at dressmaking sought a post as a useful companion and an experienced nurse wished to take entire charge of one or two children. ${ }^{186}$ There were no further ads till 1918, when three English ladies

184. Bob Hitchcock, Bwana-Go Home (Cape Town: Howard Timmins, 1973), pp. 92-93; Ilsa Schuster, "Constraints and Opportunities in Political Participation: The Case of Zambian Women," Geneve-Afrique 21 (1983), pp. 16-17. Mama UNIP died in June 1986. Some of her accomplishments are described in a news story, "Chikamoneka: Shining Example to Women," Zambia Daily Mail, June 24, 1986, p. 4.

185. Stephen A. Mpashi, Betty Kaunda (Lusaka: Longmans of Zambia, 1969), pp. 15-16.

186. Livingstone Mail, May 4, 1912. 
sought positions as governesses. ${ }^{187}$ In 1919 a nursery governess wanted a post in Livingstone, a boarding-house keeper in Livingstone requested a native or coloured cook, and Lusaka's chief quarry operator, G. Marrapodi, requested a "Coolie" or "Chinaman" as gardener. ${ }^{188}$ The last two listings are among the few ads for nonwhite household workers before World War II, and include the only request I found for a Chinese worker. From the early 1920s to 1938 white women regularly advertised themselves as governesses or children's nurses, using such terms as "English," "refined," and "domesticated" to indicate their suitability for work in colonial white households.

Who were these women, and where did they come from? The number of white women who came out on their own from England to work in private household service must have been small, for overseas passages were expensive. Unlike in South Africa, there was no recruitment scheme to bring Englishwomen to Northern Rhodesia for such work. I have found no indication of such women being recruited to Northern Rhodesia, although it is conceivable that persons with contacts in South Africa engaged women from this pool. ${ }^{189}$ During World War I, some of the white women who went into household service may have been wives of men who went to the front leaving them with few economic means. As I noted in Chapter 1, their presence in service made authorities hedge on launching a registration scheme in the 1920s; it was felt to be beneath the dignity of a white woman, even if poor, to have to register.

These white women did not do the dirty and heavy domestic work; that always remained the job of African men. Through the 1920s and 1930s, white women worked as governesses in colonial households who could pay as, for example, the English gentlewoman, "lately from home," who in 1924 advertised her "wide teaching experience, languages, advanced pianoforte, singing, kindergarten, and dancing." 190 The need for governesses arose from the lack of schools. Before the depression, the educational system for white children was poorly developed, and it hardly affected outlying districts. Only in 1941 did schooling become compulsory for white children between the ages of seven and seventeen who lived within reach of government schools. 191

Other white women worked as housekeepers, companions, mothers'

187. Livingstone Mail, May 10, 1918, and December 6, 1918.

188. Livingstone Mail, February 21, 1919, and November 21, 1919.

189. Charles van Onselen discusses the problematic role of white women servants on the Rand in his Studies, vol. 1, New Babylon, "Prostitutes and Proletarians, 1886-1914," pp. 103162. See also "The Crying Need of South Africa": The Emigration of Single British Women to the Transvaal, 1901-1910," Journal of Southern African Studies 10 (1983): 17-38.

190. Livingstone Mail, May 22, 1924, p. 1.

191. Gann, History, p. 344. 


\section{A Fixture of Colonial Society}

helpers, and children's nurses. Betty Clay's parents and in-laws sent a British-trained professional nurse out to Northern Rhodesia when she was expecting her first child in the late 1930s. The nurse returned to England after a year. After the birth of her second child, Betty Clay employed as nanny a middle-aged English widow who had previously come out to the colony with colleagues of the Clays' in the administration. Before marrying her late husband, a seaman, she had been a nanny in Egypt. Nanny Woods left the Clay household to marry an Afrikaans-speaking railway worker in Broken Hill. The marriage broke up, and after another period with the Clays, Mrs. Woods became a housekeeper at a hotel and eventually retired to England, surviving into her nineties. 192

Having a white woman on the staff challenged the rigid hierarchy of color, sex, and class. White women servants are likely to have been aware of their problematic status and may have used marriage as a strategy to leave service. They became scarcer, especially as the economy improved and more unmarried white men arrived. Because of increasing immigration, the demand for them grew, as indicated by the frequency of newspaper requests. Then, too, they may have priced themselves out of the market. When Eileen Bigland traveled in Northern Rhodesia in the late 1930s, she commented that "European nannies were about as scarce as ice in the Sahara-and about as expensive." 193

What happened to these women, and how many were they? Among those who were single, some married and left domestic service. Others may have set themselves up in the boarding-house and hotel trade, which was growing as a result of immigration. Some may have been young Afrikaans-speaking women from poor family backgrounds, such as the nurse girl whom colonial official S. R. Denny hired in 1937 in Lusaka when his first son was born. He described her as "a kindly soul but not very clean. We used to find piles of dust in her bed, she never seemed to wash her feet. But at least she took the hardest work off M. . . She finally went off to get married herself and was last seen . . . serving in a shop during the war." 194

The 1946 census listed a total of 193 white women in personal service, including 75 children's nurses, 41 domestic servants, 8 hotel keepers, 29 hairdressers and beauty specialists, and the rest employed in hotels and clubs. Personal service comprised the fourth-largest sector of white women's wage employment then, with 295 in government work, 260 in retail

192. Gervas amd Betty Clay, personal communiciation, July 5-6, 1986.

193. Eileen Bigland, The Lake of the Royal Crocodiles (Norwich: Hodder and Stoughton, 1939), p. 191.

194. S. R. Denny, "Up and down the Great North Road, with Some Sidesteps to East and West," unpublished papers deposited at Rhodes House, MSS. Afr. s. 113. S. R. Denny papers, quoted with author's permission. 
trade probably as shop assistants, and 250 in public service. ${ }^{195}$ These figures likely underestimate the number of white women who did householdrelated work, which may have included several young Afrikaans-speaking women who did a short stint as a mother's helper before marriage. The term "governess" disappears in the 1940s, when most requests concerned child care, and employers needed nannies and nurses. The shift in demand probably reflected improvements in the white school system, the consolidation of white family life, and the growth in immigration.

As the white sex ratio evened out and immigration increased, more white families with below-school-age children needed nannies. Through the 1940s the advertisements almost exclusively requested non-African women for work. The Polish refugee scheme in Northern Rhodesia between 1942 and the late postwar years temporarily made available a white female labor force willing to do servile work in white households. In personal reminiscences the women who employed these Polish women describe them in glowing terms. Frances Greenall took on a Polish nanny from the camp outside Lusaka when her daughter was two-and-a-half years old. Having someone to look after her child, she felt free to take a job on the vernacular newspaper Mutende. ${ }^{196}$ When Ronald and Mrs. Bush had two children aged five and seven and were stationed at Fort Jameson, they employed a Polish woman as nanny. The Poles were very good at handicrafts and mending, recalled Mrs. Bush. Mrs. Bush valued Sophia's services and was sorry to see her leave in 1948 to join her husband in England, from where the couple later went to America. ${ }^{197}$ There were communication problems, as between Maria Wawa, who knew no English, and Barbara Carr, for whom Maria worked as a nurse but who knew no Polish. But Barbara was satisfied with Maria's work: "After being used for so long to dealing with native servants, who were lazy, dirty, inefficient, incompetent, careless and rough, it was wonderful to see Mary plunge into the housework, although it was not part of her job. She put every one of my seven native servants to shame, except that to feel shame for not doing work well was quite foreign to them." 198

These accolades are somewhat clouded, however, by evidence of problems. Reports from Lusaka in 1943 indicate that white women lodged complaints about their new household workers. Their Polish nannies would take a job but leave it at a moment's notice, unconcerned with the difficulties this caused their employers. But aside from "servant problems" that

195. Report on the Census . . 1946, p. 39. The number of 193 white women employed in personal service differs from the number enumerated in Employment Table 8, p. 36, which lists 25 women under 20 and 175 between 20 and 60 years of age in personal service.

196. Frances Greenall, personal communication, October $4,1986$.

197. Mrs. Ronald Bush, personal communication, November 24, 1986.

198. Carr, Not for Me, p. 106; and Barbara Carr to Henry Antkiewicz, November 8, 1978. 


\section{A Fixture of Colonial Society}

were not very different from those white women experienced with their African menservants, there were worse matters to contend with. Rumors had been circulating concerning the sexual conduct of Polish women. The Lusaka Women's Institute under the leadership of the wife of a Methodist minister suspected the Polish women in the local camp of providing sexual services for the white officers and enlisted men of two nearby military battalions. ${ }^{199}$ Further, Polish women were alleged not only to have relations with African men, but to go so far as to openly solicit them.

Such affairs aroused great indignation and were seen as "undermining the respect due by Africans to all European women." The reputation of the Polish women never recovered. Even after the worst of the opprobrium had begun to die down, there were still "those who affirm[ed] that all the [Polish] women [were] prostitutes." But it was not only the notion of prostitution that caused the offense, white women doing manual labor was threatening in itself: "the sight of a European woman doing hard manual work such as hoeing gardens, carrying sacks of potatoes on their backs, etc. will be detrimental to the position of all European women." 200 As a result, there were some, but not many, ads for Polish nannies in the newspapers. It may be that the presence of these white women, who did manual work in colonial households and perhaps had loose sexual mores, contradicted too dramatically colonial white women's tightly upheld standards of propriety.

In the late 1940s and early 1950s, white madams were fortunate to gain access to a new female labor supply with several desirable features: the ability to speak proper English and knowledge of white housekeeping practices combined with racial characteristics that set them off from both white women householders and male African servants. These women came from the tiny island of St. Helena, in the South Atlantic Ocean, which had a reputation in Britain and South Africa for providing good servants. Its population is a late mixture of East India Company employees, officials, merchants, soldiers, slaves from Africa and Asia, especially Madagascar, some Chinese and, later, liberated African slaves. ${ }^{201}$ Despite this heterogeneity, it was a thoroughly English island according to the Annual Reports: "The language is English and the English environment has become firmly established. . . . All St. Helenians receive a primary education and their homes, social life and outlook follows entirely the English tradition."202

199. Robert I. Rotberg, Black Heart: Gore-Browne and the Politics of Multiracial Zambia (Berkeley: University of California Press, 1977), p. 237; and NAZ/SEC 9/1770. Reports on Public Opinion. 1942-1945. April, November, and December 1943.

200. NAZ/SEC 9/1770. Confidential. Central Province. Provincial Commissioner to Chief Secretary, Lusaka, April, November, and December 1943. Western Province, July 1943. 201. Colonial Annual Report on the Social and Economic Progress of the People of St. Helena (London: HMSO, 1933), p. 5.

202. Ibid. (1934), p. 5, and (1935), p. 6. 
But St. Helena had few economic resources and labor migration provided some relief. There was regular emigration to South Africa and to Britain, especially by St. Helena women, described as "by nature and habit . . . deft and polite, and admirably suited to . . employment in domestic service. "203 From 1945 a contract system existed for such prospective servants, giving them a permit to work in Britain and South Africa for two years. The scheme persisted in Britain till the late 1960s, when the provisions of the Commonwealth Immigration Act of 1962 became more strongly enforced, ${ }^{204}$ and may have ceased in South Africa in 1961 when that country became a republic and left the Commonwealth.

Whites in Northern Rhodesia during the postwar years were able to hire St. Helena women at recruiting agencies in South Africa. ${ }^{205}$ Some of these women must have entered the servant pool in Northern Rhodesia. The frequency of advertisements for St. Helena women between 1949 and 1955 indicate that they were much sought after. They must have been almost perfect workers in the eyes of householders concerned with propriety and the upkeep of civilized standards. "The main reason for employing them," recalled a contemporary, "was that they all talked perfect or nearly perfect English whereas coloureds from South Africa would have a very strong South African accent which children were likely to acquire."206 Although they had mixed racial backgrounds, St. Helena women were seen as different from coloured South African women. They were familiar with the household requirements of English life, yet, although fair, they were sufficiently distinct in racial terms for the two roles of white woman and manual worker not to coincide. They were different in racial terms from African servants and perhaps because of their socialization in the manner of the English on their small island, they may have been more conscious of their expected place in the race and sex hierarchy in the colonial situation. The former Northern Rhodesians with whom I spoke or corresponded all remembered friends who had employed St. Helena women, yet none was able to provide information based on close-range observation of these women's life and work.

The employment advertisements ceased in 1955. If most St. Helena women worked on contract permits, they may have returned to their island or left Northern Rhodesia for the Cape in South Africa.

The disappearance of St. Helena women from the servant ranks in the mid-1950s left Northern Rhodesian white women householders with four child-care options. They could employ a coloured nanny; take on an African nurse boy; hire an African woman; or decide to take charge of their children

203. Ibid. (1935), p. 6.

204. St. Helena Annual Reports (1956 and 1957), p. 9, and (1966-1967), p. 11.

205. A. St. J. Sugg, personal communication, November 11, 1986.

206. Gervas Clay, personal communication, January 15, 1986. 


\section{A Fixture of Colonial Society}

themselves. Judging from the newspaper advertisements, many white women wanted to hire coloured nannies. Persons of mixed-race background from within Northern Rhodesia were considered to be different and even less civilized than those from South Africa. In early colonial discourse they were not called coloured but half-castes and were held to have the vices of both races, and the virtues of neither. ${ }^{207}$ The term Eurafrican began to be used for them only in the 1950s. The paper advertisements only rarely requested Eurafrican women for service. When white women needed actual childcare as opposed to someone just to watch the baby-for example, if they were wage employed-they preferred to hire these coloured women of South African background, who were considered more responsible. More white women than ever before worked away from home during the post-World War II years, and they advertised continually for coloured nannies. The abundance of ads may also imply that the employment relationship had its problems.

When black African women were hired as nannies, they were not expected to be in charge or to relieve white women of the chief tasks of child care. These African nannies watched the children, amused them, and played with them. Some may have worked as Betty Kaunda did in the early 1940 s, looking after the district officer's baby for a couple of hours after school. She worked in this capacity for a couple of years for a succession of district officers' wives until she left home to go to boarding school. ${ }^{208}$ In the early fifties, Mary Thompson had African nannies for both of her sons during their first eighteen to twenty months. She described their function as "a sort of watchdog while I was at the tennis court or in the pool."209 Ishbel Stokes, herself a trained nurse, saw several such nannies pass through her household on the copperbelt in the 1950s when her two girls were small. She never allowed them to touch the children and described them all as useless, though none of them ever let her down, for example, by leaving the children alone. The most reliable and efficient nanny the Stokeses had was Maria, a beautiful Congolese woman known locally as the dance queen of the Congo. She was fabulous with the children, would entertain them with stories and games. "What our children learned," commented Roy Stokes," we never knew, or deemed wise to ask, but we are sure that [she] contributed more to their general education than many tedious hours in school." 210

White women did not always find it necessary to employ someone to help with childcare. Some sent the children to creches and nursery schools

207. Dick Hobson, personal communication, December 2, 1986.

208. Mpashi, Betty Kaunda, pp. 15-17.

209. Mary Thompson, personal communication, November 24, 1985.

210. Roy Stokes, personal communication, December 18, 1983. 
during part of the day. Many, such as Emily Bradley, who had only sons, were content to have a young African boy to push the pram and wash the nappies. A. St. J. Sugg, a colonial official, and his wife never employed an African man or woman to help with their son's and daughter's care. They would occasionally lay on one or other from the staff of menservants to amuse the children if they themselves went out. ${ }^{211}$

Black African nannies finally became a more frequent sight in white households in towns from the late 1950s and on. Like the Stokes' Maria, some of them were nonlocal Africans. When Eric Dunlop, then labor commissioner, and his wife had twins in 1962, they employed the cook's wife as nanny. She was a well educated, mature woman from Southern Rhodesia. ${ }^{212}$ Women like her had come to Northern Rhodesia together with husbands from that territory whom they had married as labor migrants in the south. These nonlocal women were by far the preferred African nannies. Few advertisements for them ran in the newspapers, which may reflect their scarcity, desirability, and the fact that they were likely to be engaged on the strength of personal recommendations. With the growing demand for child care during the late colonial period and the disappearance of white women willing to do such work, these foreign, coloured Africans and their local African sisters became the exceptions to the time-honored practice of employing mainly African men as domestic servants in colonial households. Even so, the few African women then employed did not as a rule work qua domestic servants as house, table, or kitchen workers, and they never displaced African men from these domains. The exception thus confirms the rule: colonial domestic service remained almost exclusively an African man's job.

\section{Sex and Gender in Domestic Service: Structure and Ideology}

My observations in this chapter are likely to differ from those made, for instance, by scholars and former residents of East Africa where the ayah, the female African servant, was a common sight in white colonial households. They may also be at variance with the situation in parts of Francophone Africa, for example, Mali and Senegal, where la bonne was a household fixture. And I have specifically argued that they contrasted with South African conditions from approximately 1930 onward, when women began replacing menservants.

The answer to the gender question in domestic service is complicated and no single explanation will suffice for any of these or other cases. An-

211. Sugg, personal communication, November 11, 1986.

212. Eric Dunlop, personal communication, September 27, 1986. 
Theresa Thompson, her nanny, and a friend of the nanny, 1949. From the collection of Mary and Reginald Thompson. Reproduced with permission.

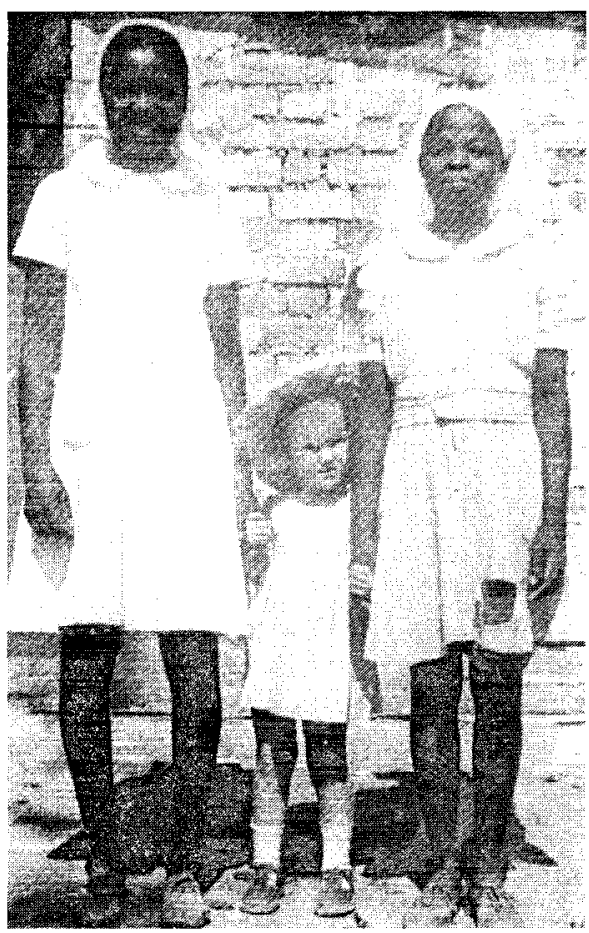

swers will everywhere depend on unraveling the changing interaction of economic, political, and demographic factors with cultural and ideological ones. These factors combine in different ways across space and time with the result that similar employment conventions, the East African ayah and the Senegalese bonne, in fact may involve explanations in which these factors carry varying weight.

In my explanation of the gender question in domestic service in Northern Rhodesia I acknowledged, first, the limits that economic, political, and demographic processes set around this occupational domain. Compared with South Africa (and Southern Rhodesia), the lower level of overall economic development, the lack of coerciveness by the local colonial government, and the smaller white population of Northern Rhodesia resulted in the much longer duration of the convention of employing man as servants. When the economy grew and both the white and the African urban populations increased rapidly during the post-World War II èra, and African men's labor power was critically needed outside of domestic service, cultural and ideological factors did not change easily to reflect this shift. On the contrary, their legacy persisted and helped as the years went on to construe the gender division of labor in domestic service in terms that 


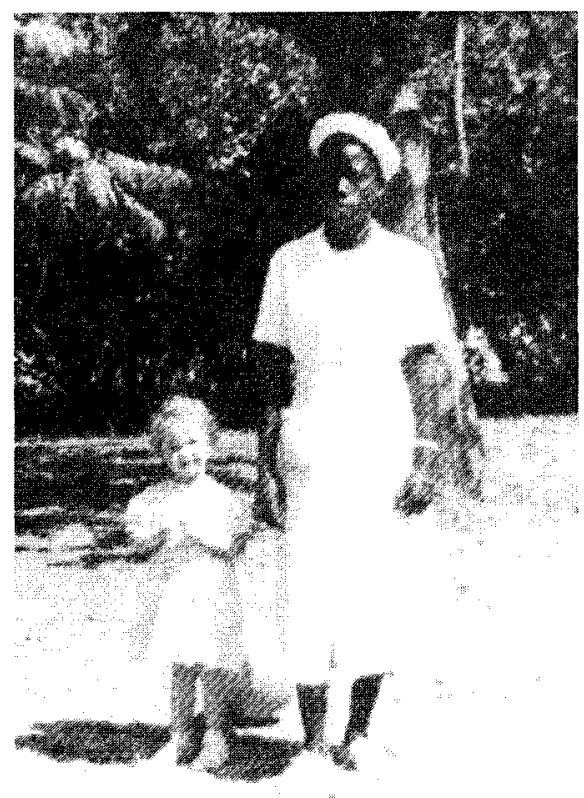

Carole Stokes and nanny, Kitwe 1955/ 56. From the collection of Ishbel and Roy Stokes. Reproduced with permission.

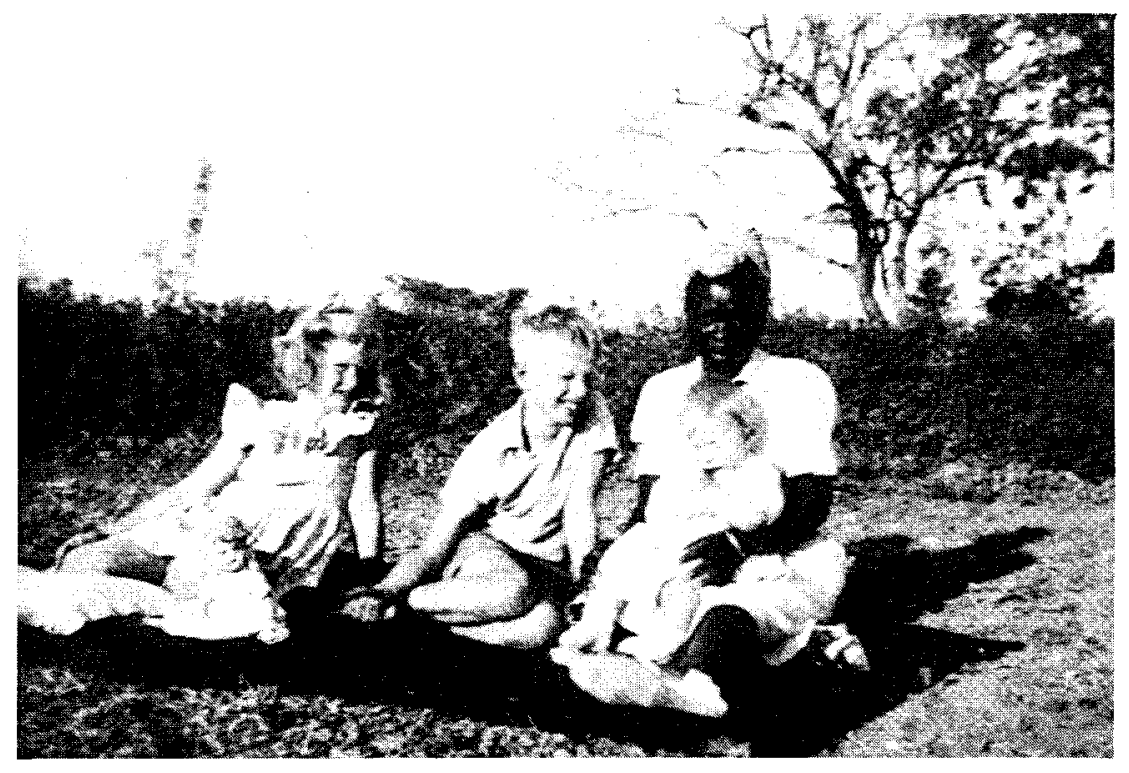

The children of the Ronald Bush household and their nanny in the garden in Lusaka. From the collection of Mrs. Ronald Bush. Reproduced with permission. 


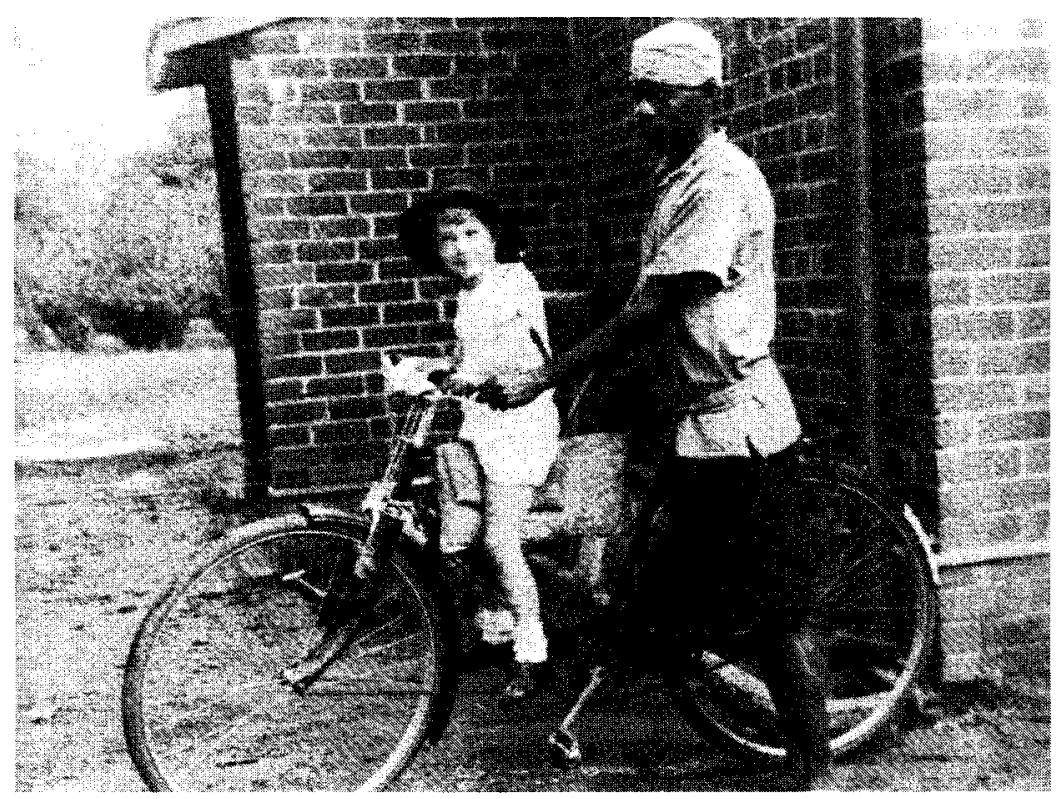

Erlbert taking Geofffrey Bush, aged 3, to nursery school. From the collection of Mrs. Ronald Bush. Reproduced with permission.

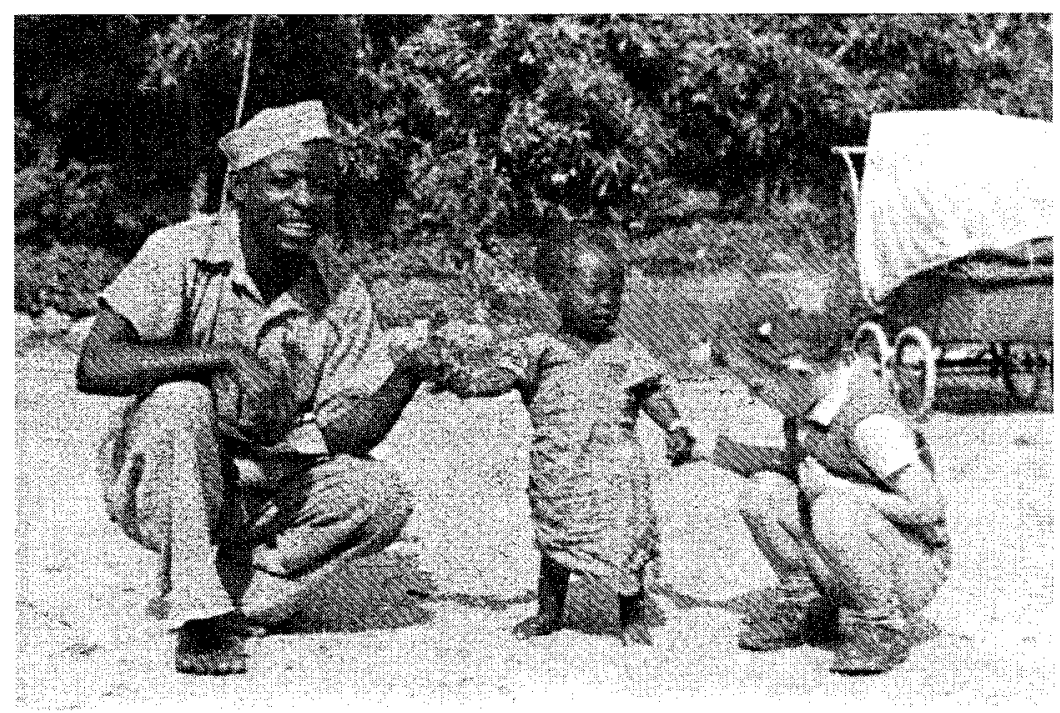

Michek, his small daughter, and Ian Thompson. Reproduced with permission. 
made African men better suited for it than women. This division of labor was so taken for granted in the outlook of white madams that they never seriously considered employing African women servants. Given the legacy of pioneer days, suspicion lingered that African women would be sexually available to the master of the house.

The second part of my argument brought these cultural and ideological factors to bear on my explanation. Recognizing the limits that broader structural factors had set around the occupation, I granted cultural and ideological factors some influence in shaping the gender division of labor in domestic service. I identified sexual anxiety as the core of this ideology and delineated the processes and interactions across race and sex that had helped bring such a belief to the fore. The issue of domestic service in white households, as Belinda Bozolli has observed, "can better be understood as the outcome of a complex series of domestic struggles, rather than as an institution designed to serve the interests of capital in an uncomplicated fashion."213 I am thus proposing neither that structural and ideological factors operate independently of one another, nor that either set of factors alone determines action, but that they both, in complex and at times contradictory interaction, shape social action and practice.

213. Bozolli, "Marxism, Feminism," p. 159. 